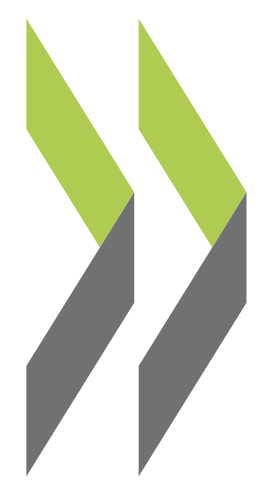

OECD Economics Department Working Papers No. 1230

Macroeconomic

uncertainties, prudent debt targets and fiscal rules
Falilou Fall,

\section{Jean-Marc Fournier}


Organisation de Coopération et de Développement Économiques

Organisation for Economic Co-operation and Development

29-Jun-2015

ECONOMICS DEPARTMENT

English - Or. English

\section{MACROECONOMIC UNCERTAINTIES, PRUDENT DEBT TARGETS AND FISCAL RULES}

ECONOMICS DEPARTMENT WORKING PAPERS No. 1230

By Falilou Fall and Jean-Marc Fournier

OECD Working Papers should not be reported as representing the official views of the OECD or of its member countries. The opinions expressed and arguments employed are those of the author(s).

Authorised for publication by Jean-Luc Schneider, Deputy Director, Policy Studies Branch, Economics Department.

All Economics Department Working Papers are available at www.oecd.org/eco/workingpapers

JT03379562

Complete document available on OLIS in its original format

This document and any map included herein are without prejudice to the status of or sovereignty over any territory, to the delimitation of

international frontiers and boundaries and to the name of any territory, city or area. 
OECD Working Papers should not be reported as representing the official views of the OECD or of its member countries. The opinions expressed and arguments employed are those of the author(s).

Working Papers describe preliminary results or research in progress by the author(s) and are published to stimulate discussion on a broad range of issues on which the OECD works.

Comment on the Papers is invited, and may be sent to OECD Economics Department, 2 rue André Pascal, 75775 Paris Cedex 16, France, or by e-mail to eco.contact@oecd.org.

All Economics Department Working Papers are available at www.oecd.org/eco/workingpapers.

The statistical data for Israel are supplied by and under the responsibility of the relevant Israeli authorities. The use of such data by the OECD is without prejudice to the status of the Golan Heights, East Jerusalem and Israeli settlements in the West Bank under the terms of international law.

\section{(C) OECD (2015)}

You can copy, download or print OECD content for your own use, and you can include excerpts from OECD publications, databases and multimedia products in your own documents, presentations, blogs, websites and teaching materials, provided that suitable acknowledgment of OECD as source and copyright owner is given. All requests for commercial use and translation rights should be submitted to rights@oecd.org 


\section{Abstract / Résumé \\ Macroeconomic Uncertainties, Prudent Debt Targets and Fiscal Rules}

The sharp rise in debt experienced by most OECD countries raises questions about the prudent debt level countries should target. It also raises questions about the fiscal frameworks needed to reach them and to accommodate cyclical fluctuations along the path towards a prudent debt target. The objective of this paper is to define long-run prudent debt targets for OECD countries and country-specific fiscal rules. To this end, a semi-structural macroeconomic model for OECD countries and primary balance reaction functions are estimated. The shocks derived from these estimations are used to assess uncertainties surrounding the development of macroeconomic variables. The model is simulated up to 2040 to derive the prudent debt target for each country and design country-specific fiscal rules.

Keywords: Macroeconomic uncertainties, debt, fiscal policy, fiscal rules

JEL codes: E27; E61; E62; H62; H68

\section{Incertitudes macroéconomiques, cibles prudentes d'endettement et règles budgétaires}

La forte hausse de la dette que connaissent la majorité des pays de l'OCDE interroge sur le niveau prudent d'endettement que les pays doivent cibler. Elle interroge également sur les cadres budgétaires nécessaires pour y parvenir et absorber les fluctuations de la conjoncture tout au long de la trajectoire vers une cible prudente d'endettement. L'objectif de ce document est de définir des cibles prudentes d'endettement pour les pays de l'OCDE et des règles budgétaires propres à chacun d'entre eux. À cet effet, on procède à l'estimation d'un modèle macroéconomique semi-structurel des pays de l'OCDE et de fonctions de réaction du solde primaire. Les chocs calculés à partir de ces estimations servent à évaluer les incertitudes entourant l'évolution de variables macroéconomiques. La simulation est effectuée jusqu'en 2040 pour déduire le niveau d'endettement prudent pour chaque pays et élaborer des règles budgétaires propres à chacun.

Mots-clés : incertitudes macroéconomiques, dette, politique budgétaire, règles budgétaires

Classification JEL : E27 ; E61 ; E62 ; H62 ; H68 


\section{TABLE OF CONTENTS}

MACROECONOMIC UNCERTAINTIES, PRUDENT DEBT TARGETS AND FISCAL RULES ............7

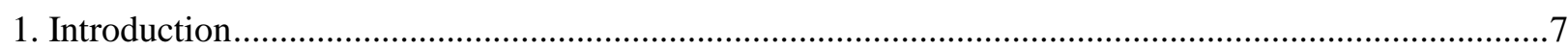

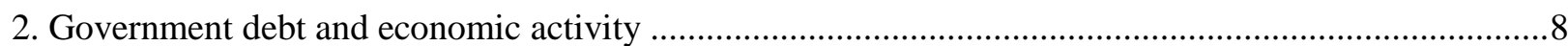

2.1. The effects of debt on the economy: lessons from economic modelling .......................................8

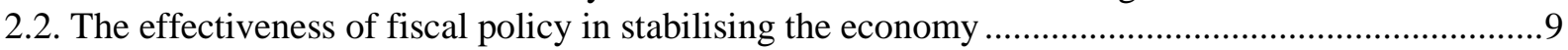

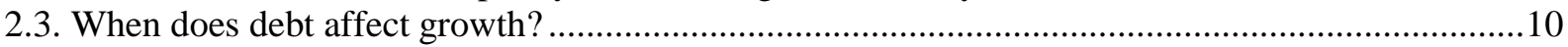

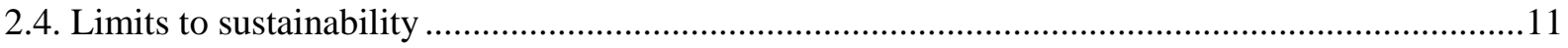

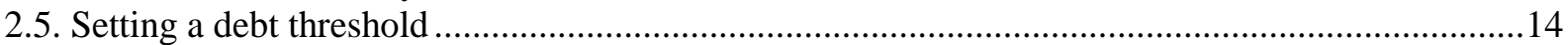

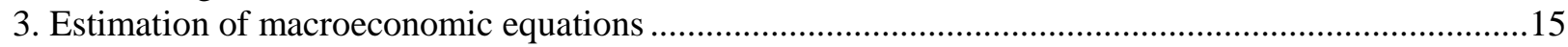

4. Simulating growth, inflation, interest rates and public debt dynamics ..............................................21

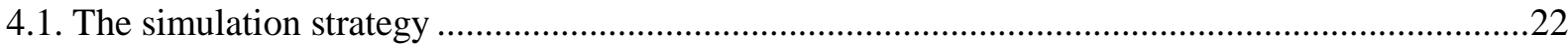

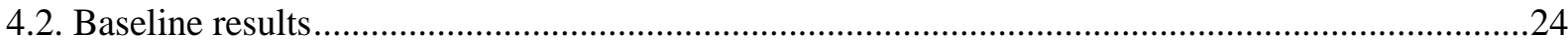

4.3. Deriving a prudent debt target from the stochastic simulations ..................................................26

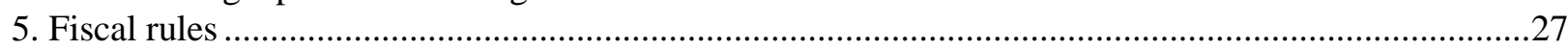

5.1. The trade-off between counter-cyclicality and debt uncertainty .............................................28

5.2. A spending rule can boost long-term growth and hence reduce recession risks .............................30

5.3. Restraining fiscal stimulus to the current year reduces debt uncertainty without adverse effects

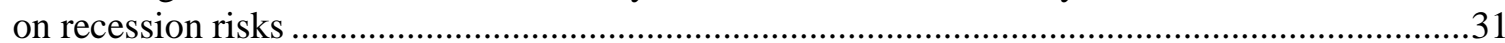

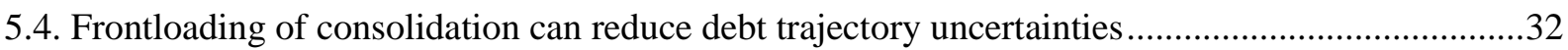

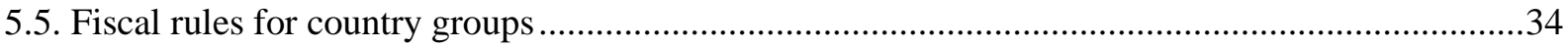

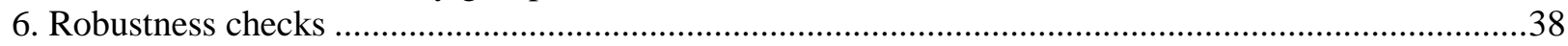

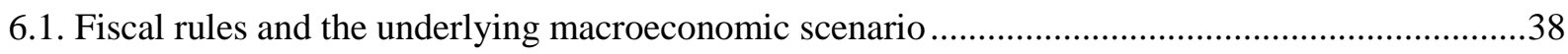

6.2. Fiscal rules and assumptions made to reach prudent debt levels ..................................................41

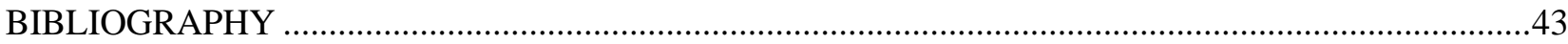

\section{Tables}

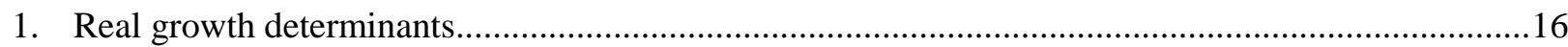

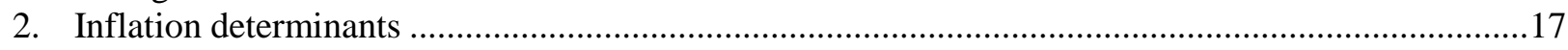

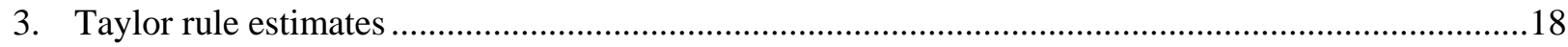

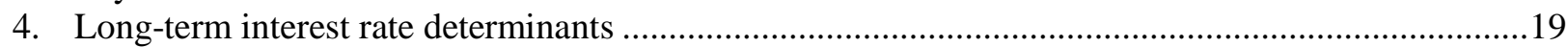

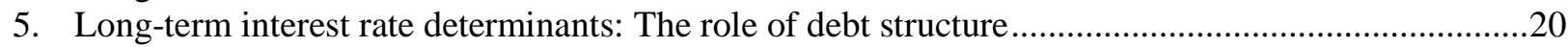

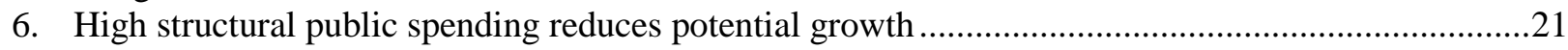

7. Simulation results: Grouping of countries and fiscal rules .................................................................

\section{Figures}

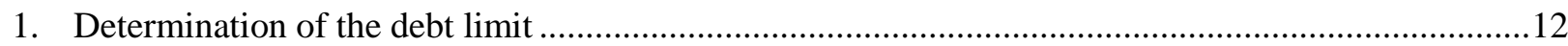

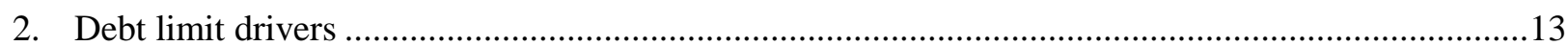

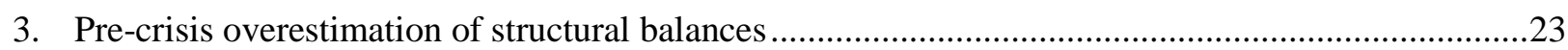

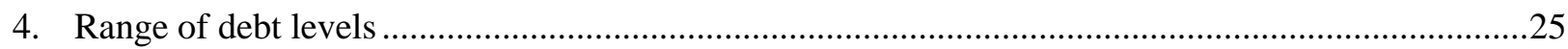




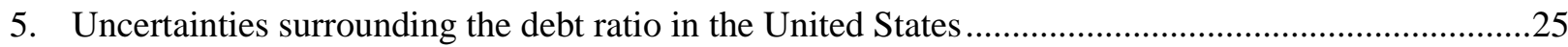

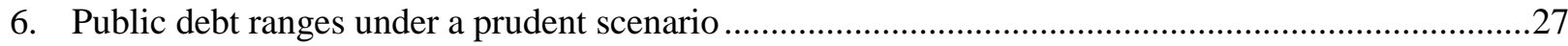

7. The trade-off between counter-cyclicality and hitting the debt target .................................................29

8. Counter-cyclical behaviour and primary balance needed to reach a prudent debt level.......................30

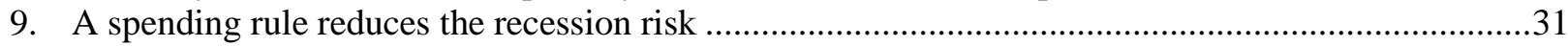

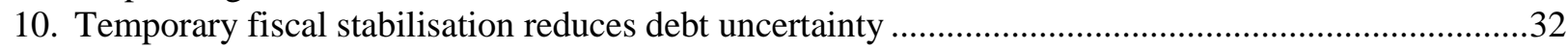

11. A debt feed-back rule reduces debt trajectory uncertainties .........................................................33

12. Including interest payments in the targeted balance reduces debt trajectory uncertainties..................34

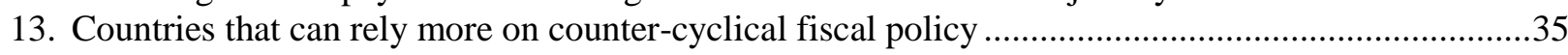

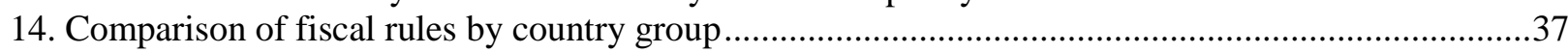

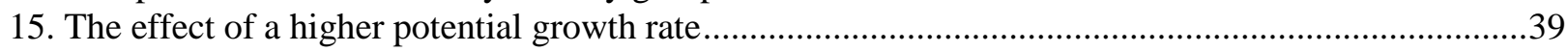

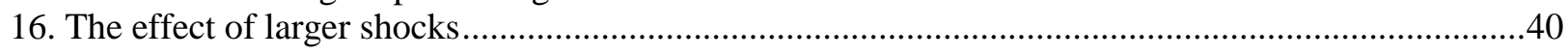

17. Net debt simulation: The example of the Netherlands .................................................................. 41

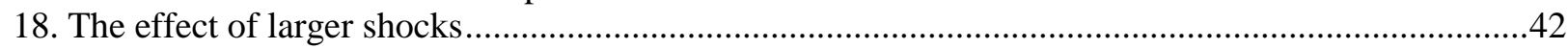

\section{Boxes}

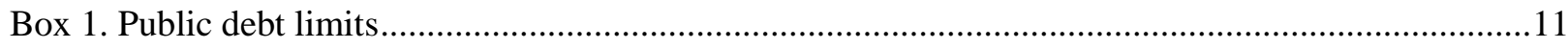

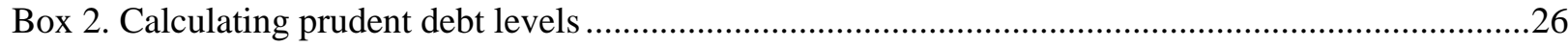


ECO/WKP(2015)48 
ECO/WKP(2015)48

\title{
MACROECONOMIC UNCERTAINTIES, PRUDENT DEBT TARGETS AND FISCAL RULES
}

\author{
By Falilou Fall and Jean-Marc Fournier ${ }^{1}$
}

\section{Introduction}

1. Most OECD countries have seen their government debt rise sharply during the global financial crisis. The OECD-wide gross debt-to-GDP ratio increased from $73 \%$ of GDP in 2007 to $111 \%$ in 2013 . $^{2}$ The sharp rise in debt experienced by most OECD countries raises questions about the prudent debt level countries should target. It also raises questions about the fiscal frameworks needed to reach them and to accommodate cyclical fluctuations along the path towards a prudent debt target, creating fiscal space to react to future shocks and taking into account countries' specificities. The definition of prudent debt targets rests on two key ingredients. First, there is a need to assess the impact of debt on the economy and in particular to find out whether there is a turning point above which negative effects of debt dominate its positive effects. Such turning points define the debt threshold that serves as a reference point that anchors the determination of a prudent debt level. Second, the degree of prudence depends on country-specific shocks and risks. Therefore, there is a need to quantify the macroeconomic uncertainties surrounding debt developments to define a prudent debt level.

2. A small structural macroeconomic model is estimated and simulated for all OECD countries (see Sorbe, 2012, for similar work on Portugal). This model embeds the main mechanisms at work for the debt accumulation dynamics, including $i$ ) the impact of interest rates and of fiscal consolidation on activity, ii) the feedback of activity and interest rates on the fiscal position, iii) the impact of public debt on interest rates and $i v$ ) the common monetary policy in the European Economic and Monetary Union (EMU). This tractable model can be used to investigate uncertainties surrounding future debt path.

3. The simulation strategy used in this paper is similar to a VAR approach (e.g. Garcia and Rigobon, 2004; Celasun et al., 2007). It is close to a constrained VAR in which most coefficients of the behavioural equations in the baseline model are estimated, while some coefficients are set to zero for the sake of parsimony. The model is closed with accounting identities. The variance-covariance matrix of the equations' residuals is extracted to simulate shocks. A simpler approach would be to extract the variance-

1. The authors are members of the Economics Department of the OECD. They thank Sebastian Barnes, Hansjoerg Bloechliger, Peter Hoeller, Christian Kastrop, Catherine Mann, Jean-Luc Schneider, David Turner, European Commission officials and participants at an internal seminar for their helpful comments, Debbie Bloch for statistical assistance and Celia Rutkoski for assistance in preparing the document. This paper is part of an OECD project on government debt and fiscal frameworks. The other papers include an OECD Economic Policy Paper (Fall et al., 2015) that summarises the whole project, a working paper that focuses on the various gross and net debt concepts that are useful in assessing fiscal risks and sustainability issues (Bloch and Fall, 2015), and a working paper that focuses on the limits to government debt sustainability (Fournier and Fall, 2015).

2. Throughout the paper, government gross debt refers to government gross financial liabilities. Different gross and net debt concepts are discussed in Bloch and Fall (2015). 
covariance of variables directly (e.g. di Giovanni and Gardner, 2008; Beynet and Paviot, 2012; Berti, 2013). However, this approach would ignore dynamic linkages between variables, such as the effect of the fiscal stance on output. This exercise provides a lower bound of uncertainties as structural parameter uncertainties and tail events are not taken into account.

4. Section 2 of this paper presents the lessons from theoretical and empirical analyses that are useful in pinning down a government debt threshold above which negative effects of debt on economic activity emerge. In Section 3, the estimation of the main macroeconomic equations that govern debt dynamics are presented. In Section 4, the model built on these estimates and the simulation strategy are described. The baseline simulation is run up to 2030 assuming that governments react in line with their past behaviour. This framework is also used to derive a prudent debt target, so that the probability of debt to go above a given debt threshold by 2040 is sufficiently low. In the fifth section, various fiscal rules are implemented in this framework, providing an assessment of their impact on recession risks and debt trajectory uncertainties. In Section 6, robustness checks are presented to show the role of the various underlying hypothesis on results.

\section{Government debt and economic activity}

\subsection{The effects of debt on the economy: lessons from economic modelling}

5. Government debt should be set at the level that maximises welfare. As it is difficult to pin down welfare, the objective can also be to maximise the growth rate of the economy. While most of the literature agrees that debt matters, there is no consensus as regards the optimal level of debt.

6. From the seminal work of Barro (1979), one key conclusion is that debt is irrelevant, if Ricardian equivalence prevails. Indeed, if households only care about the present value of their wealth, a deficitfinanced tax cut does not alter this present value. The tax cut would not affect consumption, as more private saving matches public dissaving. In this framework, debt is irrelevant and follows a random walk.

7. But Barro's results are inconsistent with empirical analyses of debt dynamics. For instance, Bohn (1998) has shown that debt-to-GDP ratios display mean-reversion over the time period of his estimations. Moreover, Lucas and Stokey (1983), in a theoretical framework with state-contingent debt and taxes, show that debt and taxes should be path-dependent. In their model, debt fluctuates around a stationary value that is a monotone function of initial debt. Thus, the results by Lucas and Stokey (1983) are consistent with debt exhibiting mean-reversion, but they offer limited insights about the determinants of long-run debt.

8. There are various reasons why Ricardian equivalence fails to hold. The main ones are: finite planning horizons, distortionary taxation and incomplete markets so that people cannot borrow against future income. An important reason for the failure of Ricardian equivalence is the distortionary effect of taxes (Auerbach and Kotlikoff, 1987; McGrattan, 1994; and Heathcote, 2005 among others). Indeed, taxes influence choices of how much and when to work, spend or produce. Economic choices depend not only on the expected present value of taxes, but also on their timing.

9. Different contributions in the literature have analysed the role of debt in a context of distortionary taxes and inflation. The main result is that debt should be limited when the government can either use money creation (inflation), taxes or debt to finance government spending. Indeed, when government cannot commit to future policy choices, it decides in each period how much to distort the economy via taxes or inflation and how much debt to leave for the future. In this case, the long-run level of debt depends on how distortive the inflation tax is (Bohn, 1998 and Martin, 2009). Inflation distorts the consumption of goods which creates an incentive for the government to increase debt so as to reduce current distortions. On the other hand, inflation decreases the real value of nominal debt, so that a high debt level pushes up 
the incentive to push up inflation. At any given level of debt, whether the government increases or decreases debt depends on which of the two effects dominates. As debt increases, so do the gains from reducing it, since the non-distortive effect of inflation gains weight.

10. Quantitative assessments are ambiguous about the optimal level of debt. In these models, the smoothing properties of debt for individuals who face liquidity constraints are one determinant of the optimal quantity of debt. When capital markets are imperfect, individual savings are governed by precautionary motives and borrowing constraints. In that context, government debt has positive and negative impacts. On the positive side, government debt enhances the liquidity of individuals by providing an additional means of smoothing consumption and loosens borrowing constraints. On the negative side, the taxes to service government debt have detrimental wealth distribution (affecting low-income individuals more) and incentive effects. In addition, government debt crowds out capital through higher interest rates. In a model that contains these features, Aiyagari and McGrattan (1998) find that the welfare maximising level of debt for the US economy is positive and around 60\% of GDP. When transfers to household are taken into account, Flodén (2001) finds that when transfers are at the optimal level, welfare maximising government debt is below $-100 \%$ of GDP for the United States. Indeed, transfers enhance risk sharing and reduce inequality, while debt, though it enhances risk sharing, leads to more inequality and crowds out of capital. This implies that in the presence of transfers optimal debt is negative. Finally, in a model that matches the income distribution of the United States, Vogel (2014) also finds that the optimal level of government debt is negative: the government should accumulate assets. The steady state welfare maximising level of government debt (assets) depends on policy instruments (labour taxes, transfers) and the optimal debt level can vary by as much as $70 \%$ of GDP.

\subsection{The effectiveness of fiscal policy in stabilising the economy}

11. The short-run impact of debt on the economy has been analysed by fiscal multipliers, which show the effect of a change in a fiscal instrument on economic activity. During the recent crisis the size of these multipliers has attracted much attention, with those favouring a stimulation of the economy arguing they are large, while those favouring fiscal consolidation claiming that they are small.

12. The empirical evidence is not conclusive, as multipliers depend on whether policy focuses on spending or taxes, whether policy changes are temporary or permanent, whether stimulus is provided in good or bad times, whether many households are liquidity constrained, on monetary policy, the credibility of government and many other factors (Galí et al. (2007), Smets and Wouters (2007), Auerbach and Gorodnichenko (2012a), Blanchard and Leigh (2013) and Ramey (2011)).

13. The level of debt also matters for fiscal policy effectiveness. Roehn (2010) provides an overview of recent studies on the private/public saving offset of fiscal stimulus and reports that the offset is larger in the long term than in the short term. However, estimates vary considerably across the studies. The estimates of the private saving offset for OECD countries ranges from 0.1 to 0.5 in the short run, and from about 0.3 to as much as 0.9 in the long run.

14. Roehn's (2010) own estimations that take into account cross-country heterogeneity in the reaction to deficit financing show that on average across countries the savings offset is around $40 \%$, both in the short and in the long term. However, there is considerable heterogeneity across countries. Overall, his results provide evidence against a strict version of the Ricardian equivalence hypothesis in the long term (full offset). Moreover, offsets may also react in a non-linear way. Saving offsets become stronger at a tipping point of government debt at around $75 \%$ of GDP, consistent with the expectation of an increased likelihood of subsequent consolidation or higher interest payments. 
15. More recently, Nickel and Tudyka (2014) find for a sample of 17 European countries that responses of output to government spending shocks exhibit a strong non-linear behaviour. In an estimation framework which allows the parameters to change continuously, they find that the overall cumulative effect of a spending shock on GDP is positive at moderate debt-to-GDP ratios, but the effect turns negative as the ratio increases. While in the short run a positive government spending shock has positive effects on real GDP, the overall effect becomes negative beyond debt ratios of $65 \%$ to $70 \%$.

16. This non-linear effect of debt is also confirmed by Turner and Spinelli (2013) who show that the interest rate effect of marginal increases in external or government debt is non-linear and depends on the initial level of debt. For instance, the interest rate effect has risen sharply in the post-crisis period for euro area countries which have a combination of both high external and government debt.

\subsection{When does debt affect growth?}

17. A high level of debt not only lessens the effectiveness of fiscal stimulus, it can also reduce growth. Reinhart and Rogoff's (2010) conjecture that debt above 90\% of GDP has a negative impact on growth has prompted much empirical work to investigate the relationship between debt and growth. ${ }^{3}$ Some studies, such as Kumar and Woo (2010) and Cecchetti et al. (2011) find some evidence of a non-linearity, with high levels of debt having a negative impact on growth. In particular, Cecchetti et al. (2011) find that government debt has a negative impact beyond a range of 80 to $100 \%$ of GDP. Moreover, Baum et al. (2013), focusing on 12 euro area countries for the period 1990-2010, estimate that beyond high debt-toGDP ratios (above 95\%), additional debt has a negative impact on economic activity.

18. These results have been challenged by Égert (2013) who determines the threshold values (if any) of debt-to-GDP ratios endogenously. ${ }^{4}$ Overall, Égert's (2013) results indicate that a universal non-linear relation between debt and growth is not robust. For general government debt, the threshold beyond which negative growth effects kick in is at about $50 \%$. Individual country estimates reveal a large amount of cross-country heterogeneity. Also Afonso and Alvés (2014), using a production function approach with many controls, find different thresholds for the debt-growth relationship for some EU countries.

19. Finally, Chudik et al. (2013) estimate long-run effects with a dynamic heterogeneous panel. They show that some economies have run into debt difficulties and experienced subdued growth at relatively low debt levels, while others have been able to sustain high levels of indebtedness for prolonged periods and grow strongly. Chudik et al. (2013) do not find a universal threshold effect in the relationship between debt and growth. However, there is a statistically significant threshold effect in the case of countries with rising debt-to-GDP ratios. The debt trajectory seems much more important than the level of debt itself. Provided that debt is on a downward path, a country with a high level of debt can grow just as fast as its peers with lower debt levels.

20. For the debt and growth nexus, an important issue is causation, as low growth could also lead to high debt levels or a third factor, such as a banking crisis could cause an economic slump and a surge in debt. Endogeneity has been addressed by using lagged values of the debt-to-GDP ratio, GMM estimations and instrumental variable regressions. Overall, there is good reason to believe that causation runs both ways and the empirical literature has not come to a strong conclusion on causality (Panizza and Presbitero, 2014).

3. The Reinhart and Rogoff (2010) results have been challenged by Herndon, Ash and Pollin (2013) after correcting for some coding errors and using a different weighting of the data.

4. Chang and Chiang (2009) used the same methodology for 15 OECD countries and find similar results. 


\subsection{Limits to sustainability}

21. As illustrated by the debt intolerance phenomenon, countries can quickly lose market confidence and see their borrowing rates increase steeply, derailing their debt trajectories. The methodology developed in this section provides a benchmark for debt limits taking into account market reactions. Following Ghosh et al. (2013), Fournier and Fall (2015) estimate a primary balance reaction function to determine debt limits, taking into account growth, interest rate developments and a country-specific average fiscal stance (Box 1). The public debt limit is defined as the maximum level of debt beyond which the government cannot roll debt over, based on a given growth and risk-free interest rate, a given level of uncertainty, and the previously observed capacity of governments to react to rising debt.

\section{Box 1. Public debt limits}

Public debt limits are calculated based on the framework by Ghosh et al. (2013). In this analysis, the primary balance reaction function is estimated differently from Ghosh et al. (Fournier and Fall, 2015). It uses a different functional form and also post-2007 data are taken into account. Using annual panel data for 31 OECD countries over the period 1985-2013, the fiscal reaction function (primary balance) depends on the debt level and control variables:

$$
\begin{aligned}
P B_{i t}=\beta_{1} G A P_{i t}+\beta_{2} O T_{i t}+ & \beta_{3}\left(D_{i t-1} 1_{D_{i t-1}<d_{1}}+d_{1} 1_{d_{1} \leq D_{i t-1}}\right)+\beta_{4}\left(D_{i t-1} 1_{d_{1} \leq D_{i t-1}<d_{2}}+\left(d_{2}-d_{1}\right) 1_{d_{2} \leq D_{i t-1}}\right)+ \\
& \beta_{5} D_{i t-1} 1_{d_{2} \leq D_{i t-1}}+\beta_{6} O O_{i t}+u_{i}+v_{i t}
\end{aligned}
$$

where $P B_{i t}$ denotes the primary balance of country $i$ at year $t, G A P_{i t}$ denotes the output gap, $O T_{i t}$ denotes the openness ratio multiplied by the terms of trade, $O O_{i t}$ denotes fiscal one-offs, $D_{i t}$ denotes the debt level and $d_{1}$ and $d_{2}$ are estimated thresholds beyond which the fiscal reaction to debt changes. $u_{i}$ are country fixed effects and $v_{i t}$ follows an $\mathrm{AR}(1)$ process.

Estimates (see Table 1 in Fournier and Fall, 2015 for the estimation results) confirm that governments react weakly by increasing their primary balance when debt increases but remains below a certain level $\left(d_{1}\right.$ in Figure 1). But, from this threshold $\left(d_{1}\right)$ to a second threshold $\left(d_{2}\right.$ in Figure 1$)$, governments react strongly to rising debt. Beyond this threshold, governments may abandon fiscal discipline and reduce the primary balance. Alternative estimates also capture the effect of the business cycle on the primary balance, and include additional control variables, such as asset prices, inflation, IMF programmes, the old age dependency ratio, the euro area or the government size.

This fiscal policy reaction function (blue line in Figure 1) is included in the debt dynamics equation and interacted with market reactions (red curve in Figure 1). The interest rate can include a risk premium reflecting the probability of default in the next period $p_{t+1}$, which is the probability that debt $d_{t+1}$ goes beyond its maximum level $\bar{d}$ :

with the following debt accumulation dynamic:

$$
p_{t+1}=P\left(d_{t+1}>\bar{d}\right)
$$

$$
d_{t+1}=\left(1+r\left(p_{t+1}\right)-g\right) d_{t}+\mu+f(d)+\varepsilon_{t}
$$

where $g$ denotes the potential growth rate, $\mu$ denotes an average stance of fiscal policy, $f(d)$ the reaction of the primary balance to debt and $\varepsilon_{t}$ captures macroeconomic shocks to the primary balance. The debt limit is a function of the interest rate-growth rate differential $r_{i}-g_{i}$, the shock size $V\left(\varepsilon_{i}\right)$, and the average past primary surplus $\mu_{i}$. 


\section{Box 1. Public debt limits (cont)}

Debt stabilises when the effect of past debt accumulation is exactly offset by the primary balance, as illustrated in Figure 1. There is a stable equilibrium $\underline{\mathrm{d}}$ at which the government generates a higher surplus if a shock increases the debt ratio. By contrast, when the debt level approaches the debt limit, then the government is facing an interest rate spiral (green curve in Figure 1), and at the debt limit, the interest rate goes towards infinity, which means that the government loses market access.

\section{Figure 1. Determination of the debt limit}

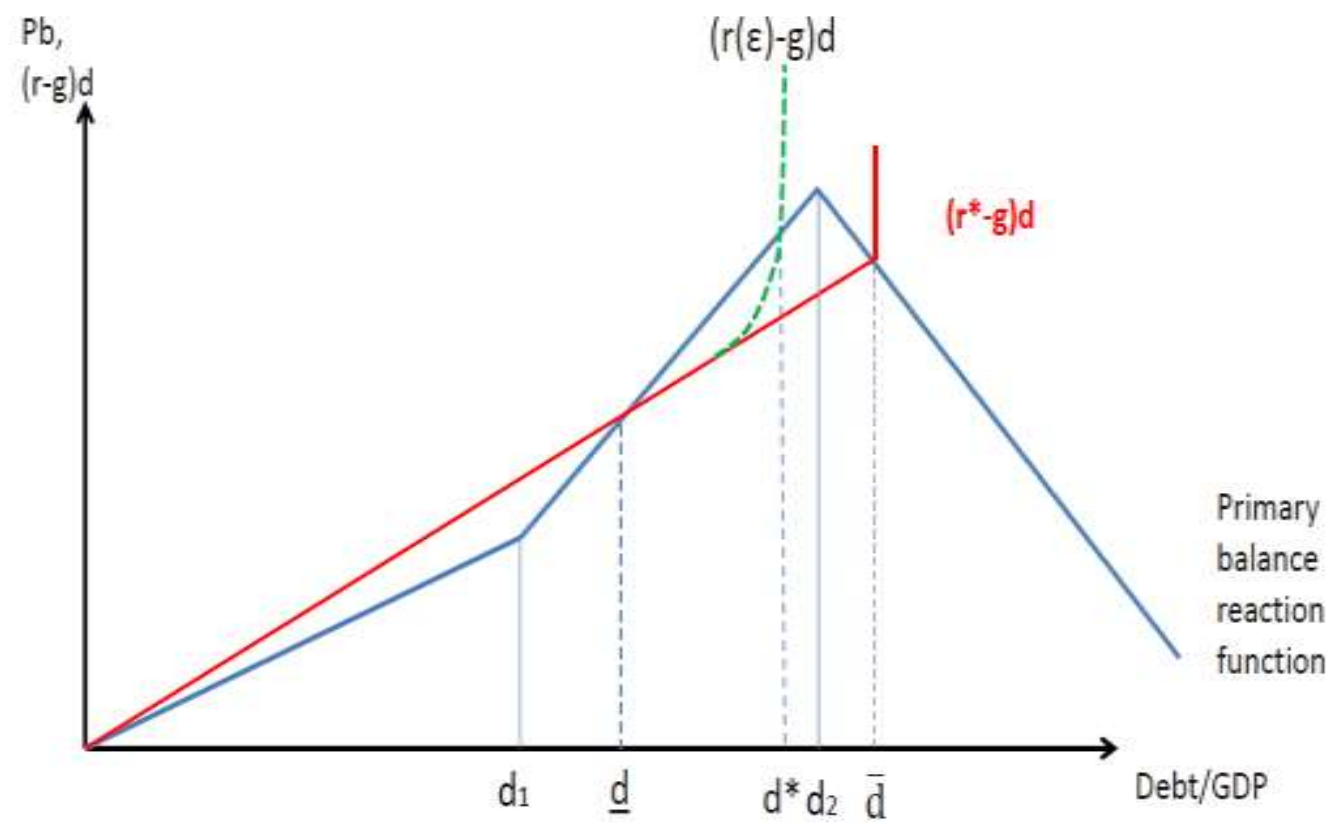

The model is solved for each country to calculate current debt limits. The real long-term interest rate is the 10 -year government bond yield minus core inflation and the real risk free rate is set by deducting the CDS risk premium from the real interest rate. The growth rate is the average potential growth rate between 2014 and 2017 , thus reflecting current expectations. The size of macroeconomic shocks is derived from the standard deviation of the output gap. The past primary surplus is gauged by country-specific fixed effects plus the median of residuals.

The gap between the interest and growth rate plays a large role in explaining differences in the debt limit across OECD countries, especially for the countries that depart most from the OECD average (Figure 2). 


\section{Box 1. Public debt limits (cont)}

Figure 2. Debt limit drivers

Deviation of the debt limit from the OECD average in per cent of GDP

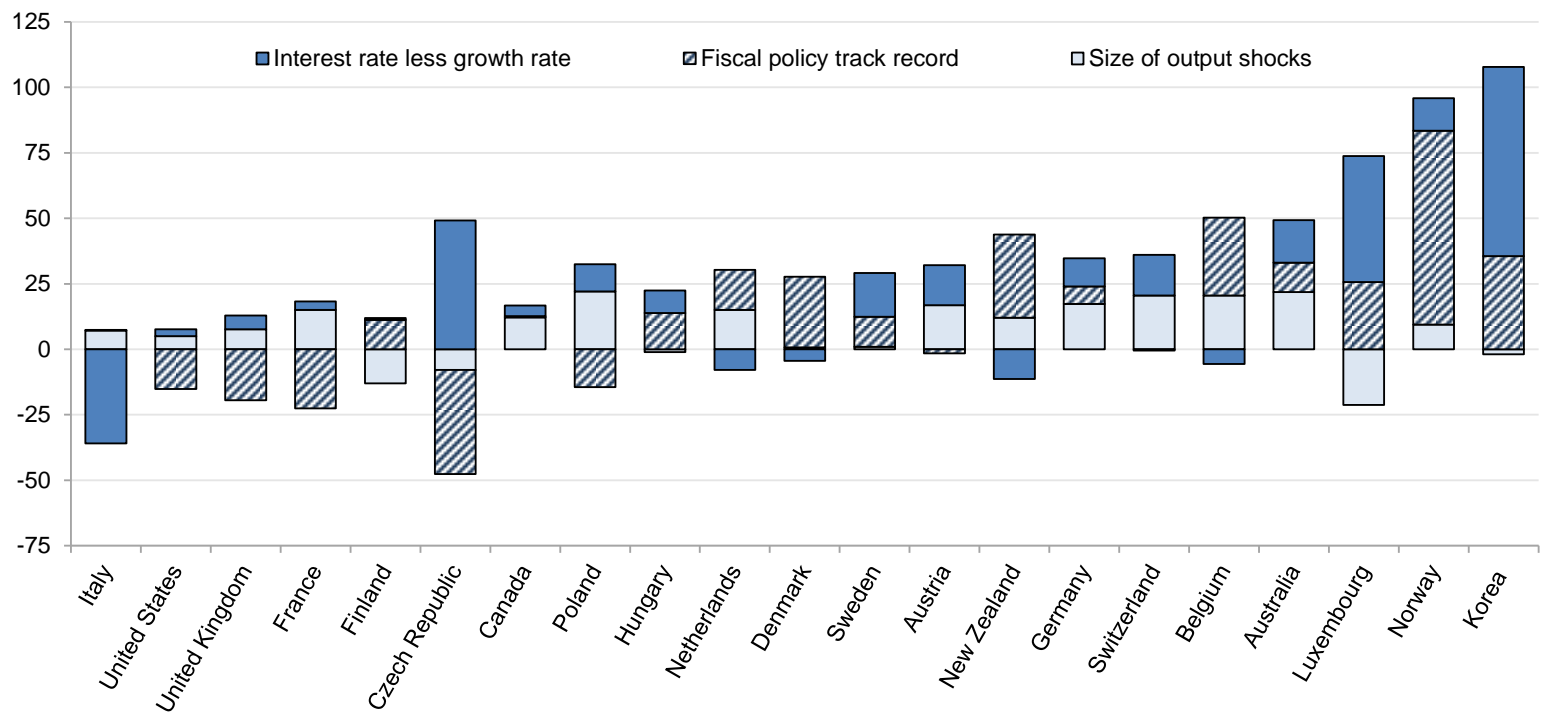

Note: This figure compares the debt limit of a country to the $200 \%$ debt limit that would prevail in a virtual OECD average country in which each determinant is equal to the corresponding OECD average. Contributions are debt limit changes associated with replacing a given country-specific characteristic by the corresponding OECD average. For more details on this decomposition, see Fournier and Fall (2015).

Source: OECD calculations.

22. The debt limit is a moving target as it can be reached quickly, if a country loses market confidence or if macroeconomic conditions change sharply (e.g. a change in the rate of potential growth or in the size of shocks). Therefore, any debt target should be substantially lower than such debt limits as uncertainties surrounding the underlying hypothesis (e.g. on long-term growth rates) and the risk of interest rate spirals call for a substantial buffer.

23. The risks of approaching a fiscal crisis are illustrated by the following mechanisms (Fournier and Fall, 2015):

- Self-fulfilling debt crisis can occur at debt levels much lower than the debt limit.

- Estimated debt limits crucially depend on past fiscal behaviour: deteriorating fiscal balances not only push public debt up, but also push the debt limit down.

- An increase in the gap between the risk free interest rate and the potential growth rate that is plausible by historical standards could force governments to change fiscal behaviour to remain on a sustainable track. An increase (decrease) in the potential growth rate improves (worsens) the debt limit: a one percentage point higher potential growth rate increases the debt limit by about $25 \%$ of GDP. In the case of a large permanent decrease of potential growth without a commensurate decrease of the risk-free interest rate, the fiscal space could also vanish unless the government changes its behaviour. Fournier and Fall (2015) show debt limits for different combinations of the interest rate/potential growth rate differential. 
- The fiscal behaviour of countries with high debt levels varies. In particular those under market pressure (e.g. euro area countries) have to generate primary surpluses, while those under no pressure (e.g. Japan) may even widen the primary deficit, although their debt is already very high.

\subsection{Setting a debt threshold}

24. From the review of the cross-country evidence of the links between government debt and economic activity, the following can be gleaned:

- At moderate levels, government debt plays a positive role for the functioning of domestic financial markets as it provides a safe asset in a very liquid market. It is difficult to pin down the size of this positive effect and when diminishing returns set in.

- Debt also plays a positive role when it funds public infrastructure, but only up to a point. The analysis suggests that this point lies between 50 and $80 \%$ of GDP for OECD countries (Fall et al., 2015, Checherita-Westphal et al., 2014 and Strasky, 2015).

- Empirical estimates of non-linear effects of debt on growth, though controversial, show that negative effects of debt on growth are likely to emerge for debt-to-GDP ratios above 80 to $100 \%$ of GDP.

- Roehn (2010) showed that at higher debt, private saving offsets of fiscal stimuli become stronger, with a tipping point estimated around 75\% of GDP. Also, Nickel and Tudyka (2014) find that the overall (short and long-run) effect of spending shocks becomes negative beyond debt ratios of $65-70 \%$.

- Sustainability limits are hard to pin down, but are high for many countries. Japan illustrates that some countries can have a high level of debt for a long time period without adverse market reactions, as the Japanese economy is characterised by a high household saving rate, low external financing and a large amount of external financial assets. The fiscal limit exercise suggests that a country may only be able to live with very high debt as long as interest rates are low and market confidence is high. This suggests that such an equilibrium is likely to become unstable. Because debt limits are state dependent, countries should endeavour to remain far below their default limit.

25. Overall, the empirical estimates suggest a gross debt threshold range, where negative effects of debt start to dominate, of 70 to $90 \%$ of GDP for higher-income countries. Specific risk exposures to factors such as foreign debt, bank fragilities, etc., should also be taken into account (Bloch and Fall, 2015). ${ }^{5}$

26. Different lessons can be drawn from the recent experience of advanced countries compared with past developing and emerging country debt crises. First, the debt intolerance phenomenon that kicked in for developing and emerging countries at low levels of debt may also affect advanced countries though at higher levels of debt. Duress involves a vicious cycle of loss of market confidence, rising interest rates on government debt, and difficulties to service debt, potentially leading to default or restructuring. This scenario is clearly what happened in the euro area, in Greece and its contagious effects. Second, as some advanced countries are more and more dependent on capital inflows and international markets for their debt financing, they are more vulnerable to global factors that could reverse financing flows and shake

5. The establishment of this debt threshold range is not based on a complete meta-analysis of all studies and there is no weighting of the various links between debt and economic activity. 
market confidence. Finally, in advanced economies fiscal risks are often linked to financial markets crises originating either internally or externally.

27. Recent events suggest that debt thresholds for euro area countries are lower than for the other advanced OECD economies, because they are constrained by the absence of a country-level monetary policy. Federal countries can provide insights for countries in a monetary union. In federations two countervailing forces exist. On the one hand, tight economic and monetary integration can make for high shock absorption capacity, as shown by large federal countries such as Canada, Germany and the United States (Hepp and von Hagen, 2009 or Carlino and Inman, 2013). On the other hand, the sharp reaction of financial markets to crises in small sub-national jurisdictions shows that even small events can have severe disruptive effects, giving credence to the argument that contagion poses a considerable threat in an integrated economy (Blöchliger, 2013). The net effect of setting risk-spreading integration against risk-creating contagion should tilt the euro area country debt targets in the direction of prudence, as capital markets are highly integrated in the euro area, leading to contagion risks, while labour and goods markets are less well integrated, making adjustment to shocks tougher and more long-lasting than in mature federations. These considerations would suggest that the debt threshold for euro area countries is in a range of 50 to $70 \%$ debt to GDP, though the "right" threshold is difficult to establish.

\section{Estimation of macroeconomic equations}

28. In this section, the estimation of the main equations that govern debt dynamics is presented. The small macroeconomic model consists of dynamic equations of real GDP growth, inflation, short and longrun interest rates, and the primary balance. These variables determine the debt dynamics. The equations are estimated with annual panel data (Economic Outlook 95) between 1985 and 2013: the real growth rate $g_{i t}$ of country $i$ at year $t$, the inflation rate measured by the GDP deflator $\pi_{i t}$, the overnight nominal interest rate $r_{i t}^{S}$, the long-term nominal interest rate $r_{i t}^{l}$ and the primary balance $P B_{i t}$ as a per cent of GDP.

29. The variables are assumed to be stationary, which is a credible assumption for most of these variables in most OECD countries. In addition, even in near unit root set ups, a VAR approach produces consistent estimates (Rothenberg and Stock, 1997), and hence the VECM approach is not considered here.

30. The equations are estimated with country fixed effects to control for unobserved heterogeneity. Reverse causality is mitigated by the use of lagged explanatory variables in most cases. As persistence in the error term would render such lagged terms endogenous, residuals are modelled as an AR(1) process (growth, interest rates and fiscal reaction function equations) or the lagged dependent variable is added as a determinant (inflation equation). For the estimation of the size of uncertainties, reduced form equations are appropriate as they produce consistent estimates of the size of innovations.

31. Real growth is anchored on the potential growth rate $g^{p o t}$ in the baseline growth equation. The estimation of the growth rate dynamics is given by equation (1):

$$
\begin{gathered}
\mathrm{g}_{\mathrm{it}}=\beta_{1,1} \mathrm{GAP}_{\mathrm{it}-1}+\beta_{1,2}\left(\mathrm{r}_{\mathrm{it}-1}^{\mathrm{l}}-\pi_{\mathrm{it}-1}\right)+\beta_{1,3} \Delta \mathrm{PB}_{\mathrm{it}}^{\mathrm{st}}+\beta_{1,4} \Delta \mathrm{PB}_{\mathrm{it}}^{\mathrm{st}} 1_{\mathrm{t} \geq 2009}+\beta_{1,5} \Delta \mathrm{PB}_{\mathrm{it}}^{\text {st }} 1_{\mathrm{t} \geq 2009}+ \\
\beta_{1,6} \mathrm{emu}_{\mathrm{it}} 1_{\mathrm{t} \geq 2009}+\beta_{1,7} \Delta \mathrm{PB}_{\mathrm{it}}^{\text {st }} \mathrm{GAP}_{\mathrm{it}-1}+\beta_{1,8} \mathrm{GAP}_{\mathrm{it}-1} 1_{\mathrm{t} \geq 2009}+\mathrm{u}_{1, \mathrm{i}}+\alpha_{1, \mathrm{t}}+\varepsilon_{1, \mathrm{it}}
\end{gathered}
$$

where $P B_{i t}^{S t}$ is the structural primary balance, $G A P_{i t}$ the output gap and $e m u_{i t}$ a dummy equal to one for euro area countries.

32. The negative coefficient associated with the output gap reflects the deviation from the potential growth (Table 1), and is consistent with the way potential output is defined and calculated. Real growth is also affected negatively by the real interest rate and by fiscal consolidation. The fiscal multiplier is stronger when the output gap is negative, in line with the recent literature that found higher multipliers in times of 
crisis (Auerbach and Gorodnichenko, 2012b; Blanchard and Leigh, 2013). Growth can also be affected by the short-term interest rate and by inflation (Table 1, Column 2). The fiscal multiplier found in the baseline equation is not significantly different during consolidation and stimulus episodes (Table 1, Column 3). Public debt could have a negative adverse impact on growth beyond its impact on long-term interest rates (Table 1, Column 4). Recent estimates (Nickel and Tudyka, 2014) also show that the fiscal multiplier is getting smaller when the debt level increases, but this effect could not be confirmed here (Table 1, Column 5). Last, there is no link between the size of the government, as measured by the ratio of structural spending to GDP, and the size of the automatic stabilisers (Table 1, Column 6).

Table 1. Real growth determinants

\begin{tabular}{|c|c|c|c|c|c|c|}
\hline & (1) & (2) & (3) & (4) & (5) & (6) \\
\hline Dependent variable & $\begin{array}{c}\text { Annual } \\
\text { growth rate }\end{array}$ & $\begin{array}{c}\text { Annual } \\
\text { growth rate }\end{array}$ & $\begin{array}{c}\text { Annual } \\
\text { growth rate }\end{array}$ & $\begin{array}{c}\text { Annual } \\
\text { growth rate }\end{array}$ & $\begin{array}{c}\text { Annual } \\
\text { growth rate }\end{array}$ & $\begin{array}{c}\text { Annual } \\
\text { growth rate }\end{array}$ \\
\hline \multirow[t]{2}{*}{ Lag (Gap) } & $-0.31^{* * *}$ & $-0.28^{* * *}$ & $-0.34^{\star \star \star}$ & $-0.35^{\star \star \star}$ & $-0.35^{\star \star \star}$ & $-0.31^{* * *}$ \\
\hline & {$[0.037]$} & {$[0.037]$} & [0.044] & {$[0.042]$} & [0.042] & {$[0.037]$} \\
\hline \multirow[t]{2}{*}{ Lag (Real LT interest rate) } & $-0.10^{\star * *}$ & $-0.13^{* * *}$ & $-0.11^{\star * *}$ & $-0.11^{* * *}$ & $-0.11^{* * *}$ & $-0.10^{* * *}$ \\
\hline & {$[0.027]$} & {$[0.049]$} & {$[0.027]$} & {$[0.028]$} & {$[0.028]$} & {$[0.027]$} \\
\hline Structural primary balance & $-0.13^{\star * *}$ & $-0.13^{* * *}$ & -0.10 & $-0.08^{*}$ & 0.06 & $-0.49^{* * *}$ \\
\hline change & {$[0.046]$} & {$[0.046]$} & [0.088] & {$[0.047]$} & [0.088] & [0.293] \\
\hline Structural primary balance & $-0.41^{* * *}$ & $-0.43^{\star \star \star}$ & -0.19 & $-0.46^{\star * *}$ & $-0.37^{* * *}$ & $-0.42^{* \star *}$ \\
\hline change after 2009 & {$[0.095]$} & [0.093] & [0.165] & {$[0.095]$} & [0.098] & {$[0.095]$} \\
\hline \multirow[t]{2}{*}{ EMU after 2009} & $-0.92^{\star * *}$ & $-1.00^{\star \star \star}$ & $-0.91^{* * *}$ & $-0.94^{\star * *}$ & $-0.89^{* * *}$ & $-0.91^{* * *}$ \\
\hline & [0.298] & {$[0.29]$} & [0.299] & [0.294] & [0.292] & [0.298] \\
\hline \multirow[t]{2}{*}{ Lag (Gap) after 2009} & $-0.16^{* *}$ & $-0.19^{* *}$ & $-0.19^{\star \star}$ & -0.12 & $-0.13^{*}$ & $-0.16^{\star \star *}$ \\
\hline & {$[0.076]$} & {$[0.076]$} & {$[0.076]$} & {$[0.08]$} & {$[0.079]$} & {$[0.076]$} \\
\hline Structural primary balance & $0.031^{* *}$ & $0.032^{\star * \star}$ & 0.008 & $0.029^{* *}$ & $0.026^{* *}$ & 0.032 \\
\hline change * lag (Gap) & [0.012] & {$[0.012]$} & [0.021] & [0.013] & [0.013] & [0.012] \\
\hline \multirow{2}{*}{ Lag (Real ST interest rate) } & & $-0.11^{\star \star *}$ & & & & \\
\hline & & {$[0.042]$} & & & & \\
\hline \multirow[t]{2}{*}{ Lag (Inflation) } & & $-0.16^{\star \star *}$ & & & & \\
\hline & & {$[0.043]$} & & & & \\
\hline \multirow[t]{2}{*}{ Fiscal consolidation } & & & -0.023 & & & \\
\hline & & & {$[0.137]$} & & & \\
\hline \multirow[t]{2}{*}{ Fiscal consolidation * Lag (Gap) } & & & 0.050 & & & \\
\hline & & & {$[0.035]$} & & & \\
\hline Fiscal consolidation & & & -0.31 & & & \\
\hline after 2009 & & & {$[0.245]$} & & & \\
\hline \multirow[t]{2}{*}{ Lag (Public debt) } & & & & $-0.008^{*}$ & -0.008 & \\
\hline & & & & [0.005] & [0.005] & \\
\hline Structural primary balance & & & & & $-0.003^{* *}$ & \\
\hline change * lag (Public debt) & & & & & {$[0.001]$} & \\
\hline Structural primary balance & & & & & & 0.008 \\
\hline change * Struct. public spending & & & & & & {$[0.007]$} \\
\hline Sample & $1985-2013$ & $1985-2013$ & $1985-2013$ & $1985-2013$ & $1985-2013$ & $1985-2013$ \\
\hline Year fixed effects & Yes & yes & yes & yes & yes & yes \\
\hline Country fixed effects & Yes & yes & yes & yes & yes & yes \\
\hline $\mathrm{N}$ & 693 & 688 & 693 & 658 & 658 & 693 \\
\hline Rho & 0.320 & 0.300 & 0.321 & 0.311 & 0.308 & 0.320 \\
\hline R2 & 0.644 & 0.659 & 0.647 & 0.662 & 0.664 & 0.644 \\
\hline
\end{tabular}

Note: Panel regression with AR(1) Prais-Winsten correction and panel heteroskedasticity-robust standard errors. Standard errors are in parenthesis. Fiscal consolidation is captured by the change in the structural primary balance if positive, zero otherwise. 
33. Inflation dynamics is based on a Phillips curve (Equation 2). The output gap is used as a proxy for the unemployment rate, which is not included in this model.

$$
\text { (2) } \pi_{\mathrm{it}}=\beta_{2,1} \pi_{\mathrm{it}-1}+\beta_{2,2} \pi_{\mathrm{it}-2}+\beta_{2,3} \pi_{\mathrm{it}-3}+\beta_{2,4} \mathrm{GAP}_{\mathrm{it}-1}+\mathrm{u}_{2, \mathrm{i}}+\alpha_{2, \mathrm{t}}+\varepsilon_{2, \mathrm{it}}
$$

34. In the estimation results reported in Table 2, inflation is anchored on a fixed target as the sum of the betas is below one, albeit with a strong persistence of past shocks, which could not be fully captured by a residual following an AR(1) process. The effect of the short-term interest rate is positive (Table 2, Column 5), most likely reflecting reverse causality, and hence the interest rate is not included in the list of explanatory variables.

Table 2. Inflation determinants

\begin{tabular}{|c|c|c|c|c|c|}
\hline & (1) & (2) & (3) & (4) & (5) \\
\hline Dependent variable & $\begin{array}{c}\text { GDP } \\
\text { deflator }\end{array}$ & $\begin{array}{c}\text { GDP } \\
\text { deflator }\end{array}$ & $\begin{array}{c}\text { GDP } \\
\text { deflator }\end{array}$ & $\begin{array}{c}\text { GDP } \\
\text { deflator }\end{array}$ & $\begin{array}{c}\text { GDP } \\
\text { deflator }\end{array}$ \\
\hline \multirow[t]{2}{*}{ Lag (GDP deflator) } & $0.61^{* \star *}$ & $0.70^{\star \star \star}$ & $0.62^{* \star *}$ & $0.58^{* * *}$ & $0.62^{* \star \star}$ \\
\hline & [0.032] & {$[0.017]$} & [0.032] & [0.034] & [0.033] \\
\hline \multirow[t]{2}{*}{ Lag (GDP deflator, 2) } & $-0.067^{*}$ & & $0.085^{\star * *}$ & -0.053 & $-0.101^{\star \star \star}$ \\
\hline & [0.038] & & [0.029] & [0.038] & [0.038] \\
\hline \multirow[t]{2}{*}{ Lag (GDP deflator, 3) } & $0.16^{\star \star *}$ & & & $0.11^{* \star *}$ & $0.14^{\star \star *}$ \\
\hline & [0.028] & & & {$[0.037]$} & [0.028] \\
\hline \multirow[t]{2}{*}{ Lag (GDP deflator, 4) } & & & & $0.055^{\star}$ & \\
\hline & & & & [0.029] & \\
\hline \multirow[t]{2}{*}{ Lag (Gap) } & $0.083^{* * *}$ & $0.077^{* * *}$ & $0.070^{* * *}$ & $0.086^{* * *}$ & $0.089^{* * *}$ \\
\hline & [0.026] & [0.025] & [0.026] & {$[0.026]$} & [0.025] \\
\hline \multirow[t]{2}{*}{ Lag (Short-term rate) } & & & & & $0.051^{* *}$ \\
\hline & & & & & [0.023] \\
\hline Sample & $1985-2013$ & $1985-2013$ & $1985-2013$ & $1985-2013$ & $1985-2013$ \\
\hline Year fixed effects & yes & Yes & Yes & yes & yes \\
\hline Country fixed effects & yes & Yes & Yes & yes & yes \\
\hline $\mathrm{N}$ & 748 & 794 & 771 & 724 & 739 \\
\hline Adj. R2 & 0.664 & 0.661 & 0.659 & 0.655 & 0.590 \\
\hline
\end{tabular}

Note: Linear panel regression. Standard errors are in parenthesis.

35. The short-term interest rate follows a Taylor rule (Taylor, 1993):

$$
r_{i t}^{S}=\beta_{3,1} G A P_{i t-1}+\beta_{3,2}\left(\pi_{i t-1}-\pi_{s t a r}\right)+u_{3, i}+\alpha_{3, t}+\varepsilon_{3, i t}
$$

where $\pi_{\text {star }}$ is the inflation target assumed to be equal to 2 . For the sake of consistency with the other equations, the GDP deflator is used. The estimates are very close if this inflation indicator is replaced by consumer price inflation (Table 3, Columns 2 and 3). Core inflation has a slightly stronger explanatory power (Table 3, Column 3). Monetary policy does not depend on past growth once the output gap is taken into account, in line with the Taylor rule (Table 3, Column 4). For each country in which inflation was above $8 \%$ in any year, only observations after the last year above $8 \%$ are included. Including all observations would not be representative of the current situation of OECD countries, and would make the link between the output gap and monetary policy insignificant (Table 3, Column 5). 
Table 3. Taylor rule estimates

\begin{tabular}{|c|c|c|c|c|c|}
\hline & (1) & (2) & (3) & (4) & (5) \\
\hline Dependent variable & $\begin{array}{c}\text { Short-term } \\
\text { interest rate }\end{array}$ & $\begin{array}{c}\text { Short-term } \\
\text { interest rate }\end{array}$ & $\begin{array}{c}\text { Short-term } \\
\text { interest rate }\end{array}$ & $\begin{array}{c}\text { Short-term } \\
\text { interest rate }\end{array}$ & $\begin{array}{c}\text { Short-term } \\
\text { interest rate }\end{array}$ \\
\hline \multirow[t]{2}{*}{ Lag (Gap) } & $0.29^{* \star \star}$ & $0.26^{\star \star \star}$ & $0.30^{* \star \star}$ & $0.24^{\star \star \star}$ & 0.090 \\
\hline & [0.047] & [0.054] & {$[0.051]$} & {$[0.06]$} & {$[0.069]$} \\
\hline \multirow[t]{2}{*}{ Lag (GDP deflator gap) } & $0.25^{\star * *}$ & & & $0.26^{\star * *}$ & $0.88^{* * *}$ \\
\hline & [0.072] & & & {$[0.075]$} & [0.097] \\
\hline \multirow[t]{2}{*}{ Lag (CPI gap) } & & $0.27^{\star \star \star}$ & & & \\
\hline & & [0.068] & & & \\
\hline \multirow[t]{2}{*}{ Lag (Core CPI gap) } & & & $0.49^{* \star *}$ & & \\
\hline & & & {$[0.076]$} & & \\
\hline \multirow[t]{2}{*}{ Lag (Real growth) } & & & & 0.069 & \\
\hline & & & & {$[0.056]$} & \\
\hline Sample & $1985-2013$ & $1985-2013$ & $1985-2013$ & $1985-2013$ & $1985-2013$ \\
\hline Obs. with inflation $>8 \%$ & Excluded & Excluded & Excluded & Excluded & Included \\
\hline Year fixed effects & yes & yes & yes & yes & yes \\
\hline Country fixed effects & yes & yes & yes & yes & yes \\
\hline $\mathrm{N}$ & 451 & 405 & 385 & 451 & 801 \\
\hline Rho & 0.467 & 0.420 & 0.459 & 0.476 & 0.244 \\
\hline $\mathrm{R} 2$ & 0.766 & 0.730 & 0.778 & 0.766 & 0.676 \\
\hline
\end{tabular}

Note: Panel regression with AR(1) Prais-Winsten correction and panel heteroskedasticity-robust standard errors. Standard errors are in parenthesis.

36. The long-term interest rate equation aims at capturing market behaviour (see de Grauwe and Ji (2012) and Haugh et al. (2009) among others for alternative estimates of interest rate determinants):

$$
\text { (4) } \mathrm{r}_{\mathrm{it}}^{\mathrm{l}}=\beta_{4,1} \mathrm{r}_{\mathrm{it}}^{\mathrm{s}}+\beta_{4,2} \mathrm{~g}_{\mathrm{it}-1}+\beta_{4,3} \pi_{\mathrm{it}-1}^{\mathrm{c}}+\beta_{4,4} \mathrm{D}_{\mathrm{it}-1}+\beta_{4,5} \mathrm{emu}_{\mathrm{it}} \mathrm{D}_{\mathrm{it}-1}+\mathrm{u}_{4, \mathrm{i}}+\varepsilon_{4, \mathrm{it}}
$$

where $\pi_{i t}^{c}$ denotes core inflation. The long-term nominal interest rate is determined to a large extent by the short-term interest rate (Table 4). The negative coefficient associated with the growth rate reflects the yield curve flattening, when growth becomes stronger. Markets do not seem to react more to net debt than to gross debt on average across OECD countries: the coefficients are roughly similar (Table 4, Columns 3 and 4). However, estimations suggest that markets seem to react more to gross debt in euro area countries, while markets are relatively more sensitive to net debt in other OECD countries (Table 4, Columns 1 and 2). This could reflect the fact that the headline Maastricht debt indicator in the euro area is a gross debt indicator. The links between the interest rate and debt is robust to various specification changes, such are replacing the nominal interest by the real interest rate or controlling for potential growth instead of real growth. 
ECO/WKP(2015)48

Table 4. Long-term interest rate determinants

\begin{tabular}{|c|c|c|c|c|c|c|c|c|}
\hline & (1) & (2) & (3) & (4) & (5) & (6) & (7) & (8) \\
\hline Dependent variable & $\begin{array}{c}10 \text {-year } \\
\text { interest rate }\end{array}$ & $\begin{array}{c}\text { 10-year } \\
\text { interest } \\
\text { rate }\end{array}$ & $\begin{array}{c}10 \text {-year } \\
\text { interest rate }\end{array}$ & $\begin{array}{c}10 \text {-year } \\
\text { interest rate }\end{array}$ & $\begin{array}{c}10 \text {-year } \\
\text { interest rate }\end{array}$ & $\begin{array}{l}10 \text {-year real } \\
\text { interest rate }\end{array}$ & $\begin{array}{l}10 \text {-year real } \\
\text { interest rate }\end{array}$ & $\begin{array}{c}10 \text {-year } \\
\text { interest rate }\end{array}$ \\
\hline \multirow[t]{2}{*}{ Core inflation } & 0.084 & 0.080 & 0.079 & 0.078 & $0.079^{*}$ & & & \\
\hline & {$[0.057]$} & [0.058] & {$[0.057]$} & [0.058] & {$[0.046]$} & & & \\
\hline \multirow[t]{2}{*}{ GDP deflator } & & & & & & & & -0.008 \\
\hline & & & & & & & & {$[0.026]$} \\
\hline Short-term interest & $0.55^{* * *}$ & $0.55^{* * *}$ & $0.55^{\star \star *}$ & $0.55^{\star \star *}$ & $0.58^{* * *}$ & & & $0.58^{* * *}$ \\
\hline rate & {$[0.037]$} & [0.035] & [0.037] & [0.035] & [0.029] & & & [0.031] \\
\hline Short-term real & & & & & & $0.63^{* * *}$ & $0.62^{* * *}$ & \\
\hline interest rate & & & & & & [0.039] & {$[0.037]$} & \\
\hline \multirow[t]{2}{*}{ Lag (Real growth) } & $-0.081^{* * *}$ & $-0.088^{* * *}$ & $-0.088^{* * *}$ & $-0.090^{* * *}$ & & $-0.084^{* * *}$ & $-0.096^{* * *}$ & $-0.072^{* * *}$ \\
\hline & [0.022] & [0.0225] & [0.022] & [0.023] & & [0.024] & [0.024] & [0.022] \\
\hline \multirow[t]{2}{*}{ Lag (Potential growth) } & & & & & $-0.32^{* \star *}$ & & & \\
\hline & & & & & {$[0.120$} & & & \\
\hline \multirow[t]{2}{*}{ EMU } & $-1.95^{\star \star \star}$ & $-0.49^{*}$ & -0.28 & -0.27 & $-1.85^{\star \star *}$ & $-1.65^{\star *}$ & -0.016 & $-2.15^{* * *}$ \\
\hline & {$[0.70]$} & [0.29] & [0.31] & {$[0.30]$} & {$[0.60]$} & {$[0.76]$} & [0.33] & [0.69] \\
\hline Lag (Gross public & 0.006 & & $0.013^{* *}$ & & 0.005 & $0.020^{\star * *}$ & & 0.004 \\
\hline debt) & {$[0.004]$} & & [0.005] & & [0.004] & [0.005] & & [0.004] \\
\hline Lag (Gross public & $0.023^{* *}$ & & & & $0.022^{* *}$ & $0.025^{* *}$ & & $0.023^{* *}$ \\
\hline debt) *EMU & {$[0.010]$} & & & & [0.009] & [0.010] & & [0.009] \\
\hline \multirow[t]{2}{*}{ Lag (Net public debt) } & & $0.014^{* \star *}$ & & $0.016^{\star * *}$ & & & $0.018^{\star \star \star}$ & \\
\hline & & [0.004] & & [0.004] & & & {$[0.005]$} & \\
\hline Lag (Net Public debt) * & & 0.006 & & & & & 0.009 & \\
\hline EMU & & [0.006] & & & & & {$[0.006]$} & \\
\hline Sample & $1985-2013$ & $1985-2013$ & $1985-2013$ & $1985-2013$ & $1985-2013$ & $1985-2013$ & $1985-2013$ & $1985-2013$ \\
\hline Year fixed effects & No & no & no & no & no & no & no & no \\
\hline Country fixed effects & Yes & yes & yes & yes & yes & yes & yes & yes \\
\hline $\mathrm{N}$ & 624 & 618 & 624 & 618 & 621 & 672 & 670 & 676 \\
\hline Rho & 0.55 & 0.51 & 0.53 & 0.50 & 0.59 & 0.59 & 0.56 & 0.55 \\
\hline $\mathrm{R} 2$ & 0.680 & 0.687 & 0.676 & 0.688 & 0.723 & 0.487 & 0.480 & 0.682 \\
\hline
\end{tabular}

Note: Panel regression with AR(1) Prais-Winsten correction and panel heteroskedasticity-robust standard errors. Standard errors are in parenthesis.

37. The effect of debt on the interest rate can depend on the structure of debt. In alternative regressions, the stock of debt is interacted with the share of short-term debt (by original maturity), the share of debt held by foreign creditors, and the share of debt denominated in a foreign currency. As the debt structure depends on investors' and governments' choices and hence on the interest rate, debt structure variables are used with a one-year lag to reduce the reverse causality bias. Information on debt structure is available only for a limited number of countries, for quite a short period of time. For this reason, estimates of the effect of debt structure should be taken with care and are not used in the simulations. The results illustrate the higher sensitivity of the interest rate to the debt level when the share of debt issued in foreign currency is higher (Table 5, Columns 1 and 4). The estimate is driven by the few OECD countries that issue a substantial share of debt in foreign currency, especially Hungary. If one drops Hungary from the sample, the coefficient remains significant at the $10 \%$ threshold despite the limited amount of information, and is even slightly higher. By contrast, the scarce information does not allow to identify any effect of the share of short-term debt or of the share of debt held by external creditors (Table 5, Columns 1, 2 and 3). 
Table 5. Long-term interest rate determinants: The role of debt structure

\begin{tabular}{|c|c|c|c|c|}
\hline & $(1)$ & $(2)$ & (3) & (4) \\
\hline Dependent variable & $\begin{array}{c}\text { 10-year } \\
\text { interest rate }\end{array}$ & $\begin{array}{c}10 \text {-year } \\
\text { interest rate }\end{array}$ & $\begin{array}{c}10 \text {-year } \\
\text { interest rate }\end{array}$ & $\begin{array}{c}\text { 10-year } \\
\text { interest rate }\end{array}$ \\
\hline \multirow[t]{2}{*}{ Core inflation } & -0.034 & 0.011 & -0.045 & -0.037 \\
\hline & [0.084] & {$[0.057]$} & [0.075] & {$[0.071]$} \\
\hline \multirow[t]{2}{*}{ Short-term interest rate } & $0.54^{* * *}$ & $0.52^{\star * *}$ & $0.55^{\star * *}$ & $0.55^{\star * \star}$ \\
\hline & {$[0.061]$} & [0.040] & {$[0.050]$} & [0.056] \\
\hline \multirow[t]{2}{*}{ Lag (Real growth) } & $-0.059^{*}$ & $-0.052^{* *}$ & $-0.051^{*}$ & $-0.059^{* *}$ \\
\hline & [0.033] & [0.021] & [0.026] & {$[0.030]$} \\
\hline \multirow[t]{2}{*}{ EMU } & -0.40 & -0.15 & -0.22 & -0.61 \\
\hline & {$[0.87]$} & {$[0.71]$} & [0.83] & {$[0.84]$} \\
\hline \multirow[t]{2}{*}{ Lag (Gross public debt) } & 0.015 & $0.013^{*}$ & $0.030^{* * *}$ & $0.016^{\star}$ \\
\hline & [0.012] & {$[0.007]$} & {$[0.010]$} & [0.009] \\
\hline Lag (Gross public & 0.014 & 0.003 & 0.008 & 0.013 \\
\hline debt) *EMU & [0.009] & [0.007] & [0.008] & [0.008] \\
\hline Lag (Gross public & 0.031 & 0.025 & & \\
\hline debt *ST debt) & [0.038] & [0.020] & & \\
\hline Lag (Gross public & -0.011 & & -0.015 & \\
\hline debt *FC debt) & {$[0.020]$} & & [0.018] & \\
\hline Lag (Gross public & $0.059^{\star *}$ & & & $0.049^{*}$ \\
\hline debt *FDC debt) & [0.026] & & & {$[0.025]$} \\
\hline Sample & $1995-2013$ & $1995-2013$ & $1995-2013$ & $1995-2013$ \\
\hline Year fixed effects & no & no & No & no \\
\hline Country fixed effects & yes & yes & Yes & yes \\
\hline $\mathrm{N}$ & 167 & 301 & 216 & 177 \\
\hline Rho & 0.30 & 0.39 & 0.38 & 0.31 \\
\hline $\mathrm{R} 2$ & 0.70 & 0.71 & 0.70 & 0.70 \\
\hline
\end{tabular}

Note: Panel regression with AR(1) Prais-Winsten correction and panel heteroskedasticity-robust standard errors. Standard errors are in parenthesis. ST debt denotes the share of short-term debt (by original maturity), FC debt the share of debt held by foreign creditors, and FDC debt the share of debt denominated in foreign currency.

38. In the baseline simulation, the primary balance is simulated with the fiscal reaction function estimated by Fournier and Fall (2015), described in Box 1.

39. The link between structural government spending and potential growth is investigated to be able to simulate the effect of a change in structural spending in this framework. For this purpose, the following equation is estimated:

$$
g_{i t}^{\text {potcap }}=\beta_{6,1} \mathrm{DF}_{\mathrm{it}-1}+\beta_{6,2} \mathrm{STSP}_{\mathrm{it}-1}+\mathrm{u}_{6, \mathrm{i}}+\alpha_{6, \mathrm{t}}+\varepsilon_{6, \mathrm{it}}
$$

where $g_{i t}^{\text {potcap }}$ is the potential GDP per capita growth, $\mathrm{DF}_{\mathrm{it}-1}$ is the distance to the frontier (the labour productivity gap of a country with respect to the United States) and $\mathrm{STSP}_{\mathrm{it}-1}$ is the structural spending to GDP ratio.

40. An increase in structural government spending has a sizeable negative effect on potential growth (Table 6). For instance, if the spending to GDP ratio in Finland or France were reduced to the OECD average, potential growth would increase by about $0.8 \%$ and $0.7 \%$, respectively. This finding still holds when replacing structural spending by structural receipts as a measure of the size of the government, and when controlling for the rise of the old age dependency ratio and for the size of public receipts. The effect 
is similar for countries with above and below the 2007 OECD average level of spending (37\% of GDP). This finding is also in line with recent studies that find that an increase in government size by 10 percentage points is associated with a $0.5 \%$ to $1 \%$ lower annual growth rate (Bergh and Henrekson, 2011). Beyond the overall size of the government, it is important to distinguish between productive and unproductive government spending, and between distorting and non-distorting taxation as shown in the seminal work of Barro (1990). Moreover, Kneller et al. (1999) find a negative effect of distortionary taxation and a positive effect of productive spending. Structural current spending (without investment) has an adverse effect on growth, while public investment could boost growth, albeit this effect is not significant here (Column 6). The adverse effect of current public spending probably reflects that high public spending needs to be financed by high and potentially very distortive taxation and that trend productivity growth of the public sector tends to be lower than in the private sector.

Table 6. High structural public spending reduces potential growth

\begin{tabular}{|c|c|c|c|c|c|c|}
\hline & (1) & (2) & (3) & (4) & (5) & (6) \\
\hline Dependent variable & $\begin{array}{c}\text { Per capita } \\
\text { potential } \\
\text { growth }\end{array}$ & $\begin{array}{c}\text { Per capita } \\
\text { potential } \\
\text { growth }\end{array}$ & $\begin{array}{l}\text { Per capita } \\
\text { potential } \\
\text { growth }\end{array}$ & $\begin{array}{c}\text { Per capita } \\
\text { potential } \\
\text { growth }\end{array}$ & $\begin{array}{l}\text { Potential } \\
\text { growth }\end{array}$ & $\begin{array}{l}\text { Potential } \\
\text { growth }\end{array}$ \\
\hline \multirow[t]{2}{*}{ Lag (Distance to the frontier) } & $3.48^{* *}$ & $5.06^{* * *}$ & $5.19^{* * *}$ & $3.43^{* *}$ & $4.36^{* * *}$ & $3.96^{* *}$ \\
\hline & {$[1.55]$} & {$[1.28]$} & {$[1.34]$} & {$[1.53]$} & {$[1.45]$} & {$[1.56]$} \\
\hline \multirow[t]{2}{*}{ Lag (Structural spending) } & $-0.056^{* * *}$ & & $-0.052^{* \star *}$ & & $-0.043^{* * *}$ & \\
\hline & {$[0.010]$} & & [0.012] & & {$[0.010]$} & \\
\hline Lag (Structural spending), below & & & & $-0.067^{* * *}$ & & \\
\hline 2007 average & & & & [0.018] & & \\
\hline Lag (Structural spending), above & & & & $-0.052^{* * *}$ & & \\
\hline 2007 average & & & & {$[0.011]$} & & \\
\hline \multirow[t]{2}{*}{ Lag (Structural receipts) } & & $-0.035^{\star * *}$ & -0.014 & & & \\
\hline & & {$[0.009]$} & [0.011] & & & \\
\hline \multirow[t]{2}{*}{ Old dependency ratio } & & & 0.0063 & & & \\
\hline & & & {$[0.027]$} & & & \\
\hline \multirow[t]{2}{*}{ Trend labour force } & & & & & $0.94^{* * *}$ & \\
\hline & & & & & [0.097] & \\
\hline Lag (Structural current & & & & & & $-0.065^{\star * *}$ \\
\hline spending) & & & & & & {$[0.01]$} \\
\hline \multirow[t]{2}{*}{ Lag (Public investment) } & & & & & & 0.046 \\
\hline & & & & & & [0.033] \\
\hline Sample & $1985-2013$ & $1985-2013$ & $1990-2013$ & $1985-2013$ & $1985-2013$ & $1985-2013$ \\
\hline Year fixed effects & yes & yes & yes & yes & yes & yes \\
\hline Country fixed effects & yes & yes & yes & yes & yes & yes \\
\hline $\mathrm{N}$ & 751 & 723 & 664 & 751 & 751 & 760 \\
\hline Rho & 0.89 & 0.91 & 0.89 & 0.89 & 0.89 & 0.90 \\
\hline $\mathrm{R} 2$ & 0.54 & 0.55 & 0.60 & 0.54 & 0.65 & 0.55 \\
\hline
\end{tabular}

Note: Panel regression with AR(1) Prais-Winsten correction and panel heteroskedasticity-robust standard errors. Standard errors are in parenthesis. The distance to the frontier is the relative labour productivity gap of a country with respect to the United States (in per cent), where labour productivity is the ratio between potential GDP in PPP terms and the trend labour force. In the regression of per capita growth, this ratio is replaced by GDP in PPP terms relative to the actual labour force.

\section{Simulating growth, inflation, interest rates and public debt dynamics}

41. In this section, the simulation strategy is set out. The baseline simulation of real growth, inflation, interest rates, the primary balance and gross public debt is run up to 2030 assuming that governments react in line with their past behaviour. Simulations include shocks to assess the uncertainty surrounding 
macroeconomic trajectories. This framework is then used to derive a prudent debt target, so that the probability of debt to go above a given debt threshold by 2040 is sufficiently low.

\subsection{The simulation strategy}

42. The simulation framework makes use of eight variables: on top of the five dependent variables associated with the five estimated equations, the model includes the output gap $G A P_{i t}$, the structural primary balance $P B_{i t}^{s t}$ and the debt-to-GDP ratio $D_{i t}$. All variables are simulated at the country level except the short-term interest in the euro area that is simulated jointly for all euro area members.

43. Each country is subject to six shocks: four country-specific shocks on current growth, potential growth, inflation and on the long-run nominal interest rate, a monetary policy shock, which is common for EMU countries and country-specific for others, and a common macroeconomic shock. The potential growth shock is extracted from revisions of past estimates of potential output, the common macroeconomic shock is extracted from the time fixed effect of the growth equation, and the four other shocks are extracted from each country's residuals of the estimated equations. While the common macroeconomic shock can capture to some extend the effect of global activity on each country, there is no explicit modelling of trade spill-over effects. Shocks are assumed to follow a joint Gaussian distribution, and the Cholesky decomposition of their matrix of variance-covariance is used to simulate shocks consistent with past observations, as in Garcia and Rigobon (2004) and Celasun et al. (2007) among others. 10000 Monte Carlo simulations are run from 2014 to 2040 to compute the distribution of possible outcomes. ${ }^{6}$

44. Potential output surprises are added on top of the other shocks because they can have a sizeable impact on the public finances. Structural deficits can be revised sharply in the case of a crisis as potential growth is not well measured in real time (Figure 3). In particular, the downward revision of the structural primary balance was about 7\% of GDP for Greece and about 3\% of GDP for Ireland. These revisions follow growth surprises: a simple regression suggests that on average across countries, a $1 \%$ real output shock is associated with a $0.2 \%$ revision of the level of potential output. It is not only the current potential output that is subject to revision, but also the previous years' levels, so that potential growth is less prone to revisions than the potential level.

6. For Greece, the simulation ignores shocks to interest rates in 2014 and takes into account only one half of the interest rate shocks occurring in 2015, assuming that it is under an assistance programme until mid2015. If there were an extension of the assistance programme, the debt uncertainty of Greece public debt could be reduced as shocks on market interest rate would not affect the debt dynamic. 
Figure 3. Pre-crisis overestimation of structural balances

2007 structural primary balance as a per cent of GDP

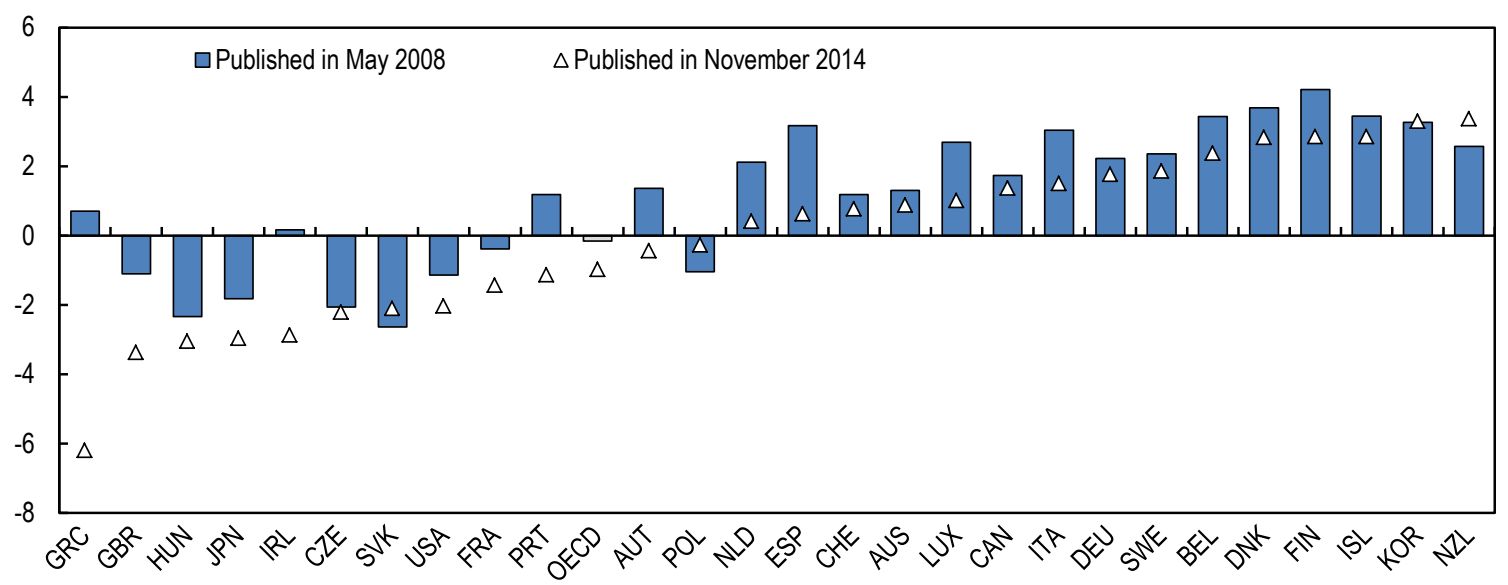

Note: The structural primary balance published in May 2008 was calculated with the available information at that time, such as the general government accounts, the provisional GDP estimate and the potential output calculated in 2008 . In practice, the difference between this publication and the latest one is mainly due to revisions in potential output, though there was also a sharp downward revision of the actual primary balance for Greece.

Source: Economic Outlook No. 83 and No. 96 databases.

45. In the simulations, fiscal policy is deterministic: the behaviour of the government is assumed to follow past behaviour or a rule, without any discretionary shock: the primary balance reacts to the macroeconomic environment.

46. The simulations are anchored on the potential growth rate $g^{\text {pot }}$ projected in the Long-Term Baseline (LTB) scenario of the OECD Economic Outlook. The convergence of actual output toward potential is ensured by the negative coefficient associated with the output gap in the estimated growth equation. The output gap is determined by the following equation:

(6) $\quad \mathrm{GAP}_{\mathrm{it}}=\mathrm{GAP}_{\mathrm{it}-1}+\mathrm{g}_{\mathrm{it}}-g_{i t}^{\text {pot }}-\varepsilon_{i t}^{\text {pot }}$

where $\varepsilon_{i t}^{p o t}$ is a shock on the level of potential output.

47. The structural primary balance and the debt accumulation process are modelled as follows:

$$
\begin{aligned}
& \mathrm{PB}_{\mathrm{it}}^{\mathrm{st}}=\mathrm{PB}_{\mathrm{it}}-0.42 * \mathrm{GAP}_{\mathrm{it}-1} \\
& \mathrm{r}_{\mathrm{it}}^{\mathrm{eff}}=\left(1-\mathrm{SD}_{\mathrm{it}}\right) \mathrm{r}_{\mathrm{it}-1}^{\mathrm{eff}}+\mathrm{SD}_{\mathrm{it}}\left(0.25 *\left(\frac{\mathrm{r}_{\mathrm{it}}^{\mathrm{s}}+\mathrm{r}_{\mathrm{it}-1}^{\mathrm{s}}}{2}\right)+0.75 * \mathrm{r}_{\mathrm{it}}^{\mathrm{l}}\right) \\
& \mathrm{D}_{\mathrm{it}}=\frac{\left(1+\mathrm{r}_{\mathrm{it}}^{\mathrm{eff}}\right) * \mathrm{D}_{\mathrm{it}-1}}{\left(1+\mathrm{g}_{\mathrm{it}}\right)\left(1+\pi_{\mathrm{it}}\right)}-\mathrm{PB}_{\mathrm{it}}^{\mathrm{st}}
\end{aligned}
$$

where the effect of the output gap on the primary balance (0.42) is taken from Fournier and Fall (2015), which is close to the estimation by Girouard and André (2005); $\mathrm{r}_{\mathrm{it}}^{\text {eff }}$ is the effective interest rate paid by the government and $\mathrm{SD}_{\text {it }}$ is the share of outstanding debt to be refinanced within the coming year as assumed in the LTB scenario of the OECD Economic Outlook. For Greece, a back-of-the-envelope calculation is made to take into account the principal repayment schedule. Countries, where the debt-to-GDP ratio 
declines to $10 \%$ are assumed to allocate further gains to financial assets purchases, so that the gross debt level cannot go below 10\%, as there can be benefits to maintaining a public debt market (e.g. Mitchell and Mosler, 2002).

48. In this framework, debt has a negative effect on growth through the rise of the interest rate and the fiscal tightening a high debt level can trigger.

49. Estimates reported in the first column of the first four tables are used in the simulations. The structural coefficients that were also estimated after 2009 are used in the simulations. In particular, the effect of fiscal consolidation on growth after 2009 is closer to the average estimate in the literature, which is slightly below unity (Gechert and Will, 2012). For the interest rate and inflation simulation, an adjustment term is added to move smoothly from the 2013 state of the economy to the LTB scenario. Core inflation is assumed to be equal to inflation as measured by the GDP deflator in the long-term interest rate equation. For the short-term interest rate equation, a common short-term interest rate is simulated for the euro area countries, making use of the weighted average output gap and inflation.

50. Seven OECD countries had to be excluded from this simulation exercise. The primary balance is not available for Chile, Mexico and Turkey and the long-term interest rate is missing for Estonia. Simulations exclude Norway because its net asset position makes this exercise irrelevant, and also because the share of debt to be refinanced within one year is not available in the OECD LTB database. Simulations also exclude Hungary and Iceland because the short period of estimation made the estimation of shock variance-covariance structures too fragile.

\subsection{Baseline results}

51. Assuming that countries do not change their fiscal reaction function, the debt-to-GDP ratio is expected to remain above $60 \%$ in about half of the countries (Figure 4). This differs from the LTB, which assumes that countries change fiscal behaviour to bring the debt-to-GDP ratio back towards $60 \%$. This shows that many countries need to change their behaviour. The wide difference between these two scenarios in some countries (e.g. Greece, Japan and Portugal) illustrates the size of the change in fiscal behaviour that is required. By contrast, the countries with a strong fiscal track record and a low level of debt such as Korea, Luxembourg or New Zealand would bring debt to its minimum level. In practice, these countries may also decide to accumulate financial assets, or adopt a less stringent fiscal stance, so that gross debt does not reach zero. In countries with a high debt level and a solid track record such as Austria or Germany, the debt level is expected to decrease substantially. The width of the confidence interval reflects the size of shocks. The uncertainties can be further magnified by the fiscal fatigue phenomenon: In a country that faces the risk to reach a high debt level characterised by fiscal fatigue, the uncertainty about the long-term debt path is further magnified. 
Figure 4. Range of debt levels under unchanged fiscal behaviour 2030, per cent of GDP

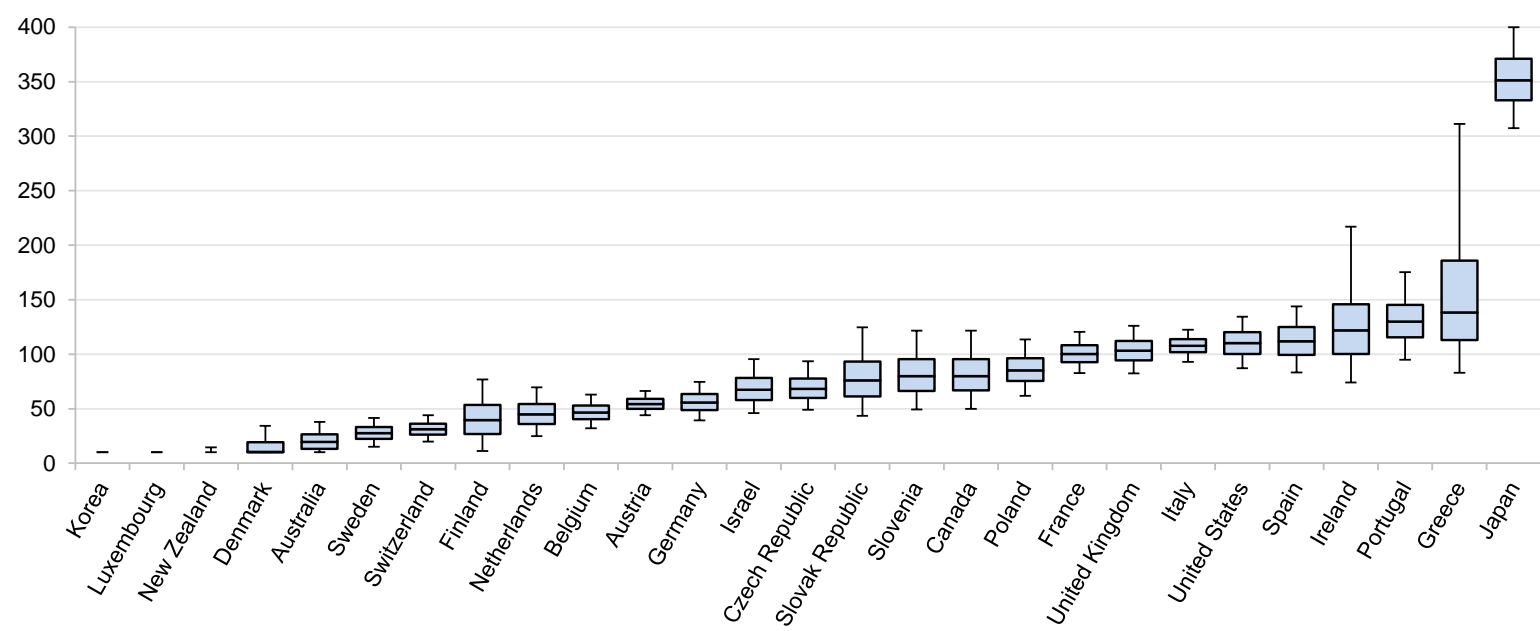

Note: The thick horizontal lines shows the median debt level, boxes show the interquartile range, and extreme values are the $5^{\text {th }}$ and the $95^{\text {th }}$ percentiles.

Source: OECD calculations.

52. The United States is taken as an example to show detailed results of these simulations (Figure 5). In the baseline scenario, the fiscal reaction function is assumed to remain in line with past behaviour. The size of uncertainties surrounding growth, inflation and the interest rate converges in the long run. By contrast, uncertainties surrounding the debt level keep increasing over time as past shocks feed into the debt accumulation dynamics. However, this divergence is somewhat softened by the fiscal reaction function which includes a feedback force on the public debt level.

Figure 5. Uncertainties surrounding the debt ratio in the United States

$\%$ change for GDP, inflation, \% for the level of interest rates and \% of GDP for the primary balance and debt ratio
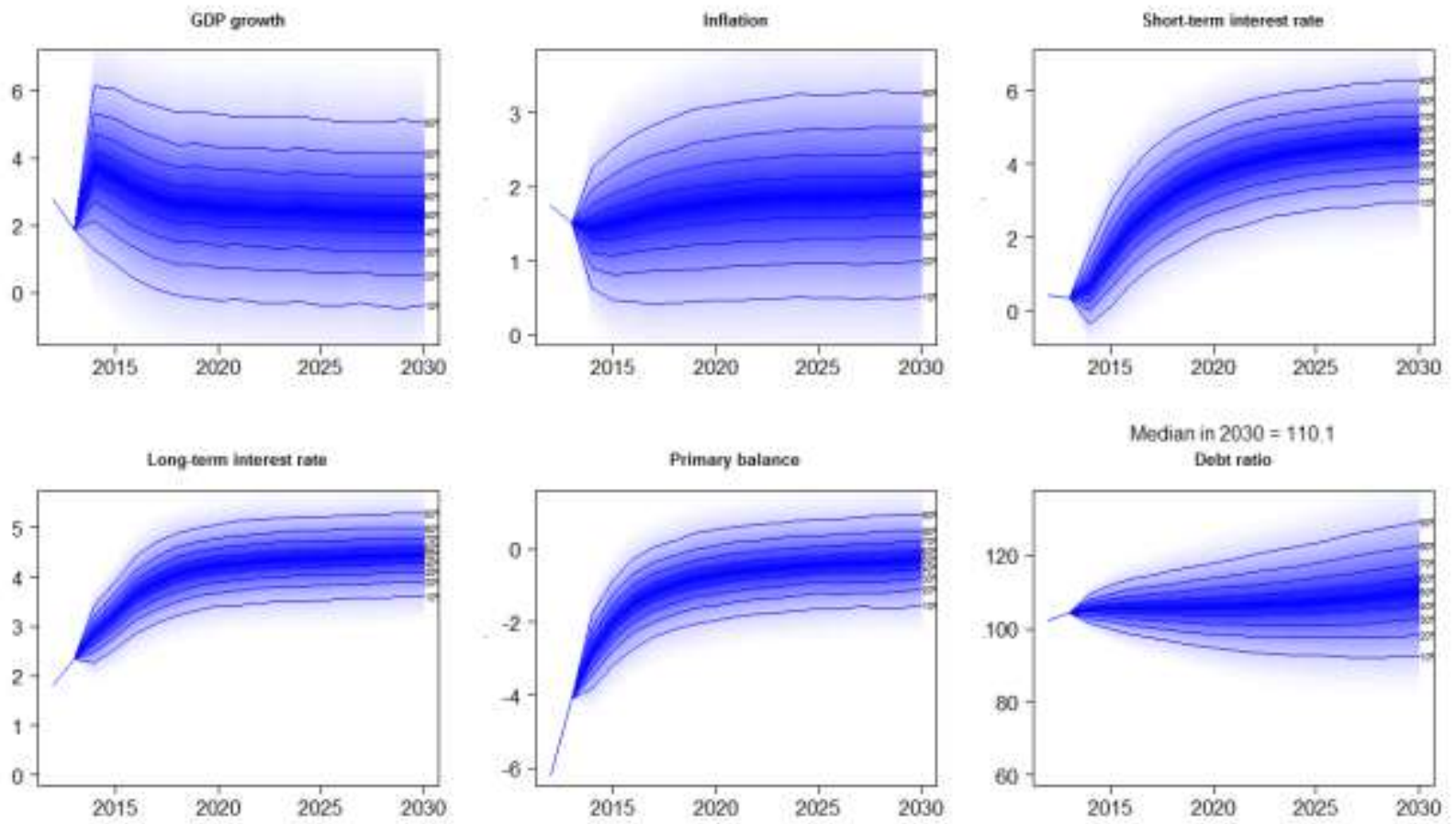

Source: OECD calculations. 


\subsection{Deriving a prudent debt target from the stochastic simulations}

53. An approach to minimise the risk of debt going beyond the threshold were it has an adverse effect on economic activity is to avoid that debt goes beyond this threshold with a certain likelihood. In practice, this can be achieved by keeping the probability that debt goes above this level sufficiently low (e.g. a probability below 25\%). In the present framework the probability of debt to go above $65 \%$ for euro area countries and $85 \%$ for other OECD countries is set at $25 \%$ as described in Box 2. Such debt thresholds reflect the survey of empirical results presented in Section 2. With the fiscal deficit trajectory that corresponds to the $25 \%$ tolerance level, the median debt level by 2040 can be regarded as the prudent debt target so that the probability to reach the pre-determined debt threshold is sufficiently low (Guillemette, 2010, makes a similar use of a "fan-chart" exercise to derive a prudent target for Canada). Larger uncertainties in a given country are associated with a lower prudent target. As illustrated in Figure 6 (Panel A), the prudent debt level ranges from about 35\% in Greece and Ireland to about $75 \%$ in the United States and the United Kingdom.

\section{Box 2. Calculating prudent debt levels}

Fiscal behaviour can be modelled by a fiscal policy reaction function $(F R F)$ that is linking the state of the economy $s_{i t}$ to the primary balance $P B_{i t}$, where the state of the economy is modelled by a set of macroeconomic variables such as the output gap, the interest rate, the debt level, the past primary balance:

$$
P B_{i t}=c_{i}+F R F\left(s_{i t}\right)
$$

where $c_{i}$ is a country-specific adjustment used to reach the debt target. For a given value of $c_{i}$, the simulation can be run, and hence the third quartile of the debt distribution at the horizon of the calculation $q_{3}\left(D_{i T}\right)$ can be regarded as a function of $c_{i}$ :

$$
q_{3}\left(D_{i T}\right)=\varphi_{i}\left(c_{i}\right)
$$

$\varphi_{i}$ is strictly decreasing an hence invertible. The country specific parameter $c_{i}$ that makes sure the probability of debt to go above $\bar{D}$ is $25 \%$ is $c_{i}=\varphi_{i}^{-1}(\bar{D})$. Once $c_{i}$ is calculated, the simulation establishing the prudent debt level can be run, and the debt target is the median debt level reached at the time horizon.

$c_{i}$ is calculated with the Newton-Raphson algorithm, and the calculation is made simultaneously for all countries to model the common monetary policy of the euro area. These calculations are made with an estimated fiscal policy reaction function as a baseline to calculate the prudent debt level (Section 4), and with stylised behaviour that reflects various types of fiscal rules (Section 5).

54. Reaching this target by 2040 would require a primary surplus in about half of the countries (Figure 6, Panel B). Greece and Japan would need to make the largest effort (an average primary surplus of $5 \%$ and $6 \%$ of GDP, respectively). In Japan, such a high surplus level is mainly due to the high starting point for the debt ratio (see Guillemette and Strasky, 2013, for a specific analysis of public debt in Japan). For Greece, on top of the high starting point, the required surplus is high because large uncertainties make the prudent debt level lower. 
Figure 6. Public debt ranges under a prudent scenario

Panel A. Prudent debt levels

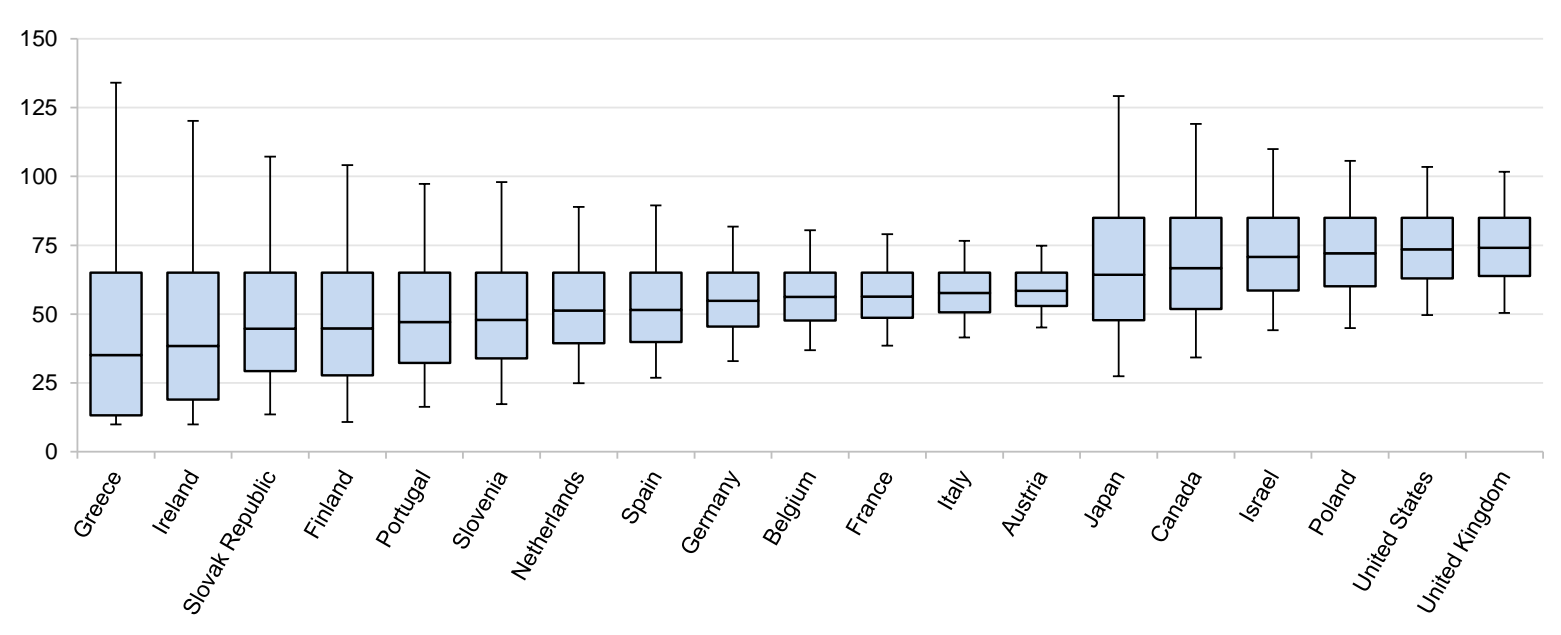

Panel B. Average annual primary balance between 2014 and 2040

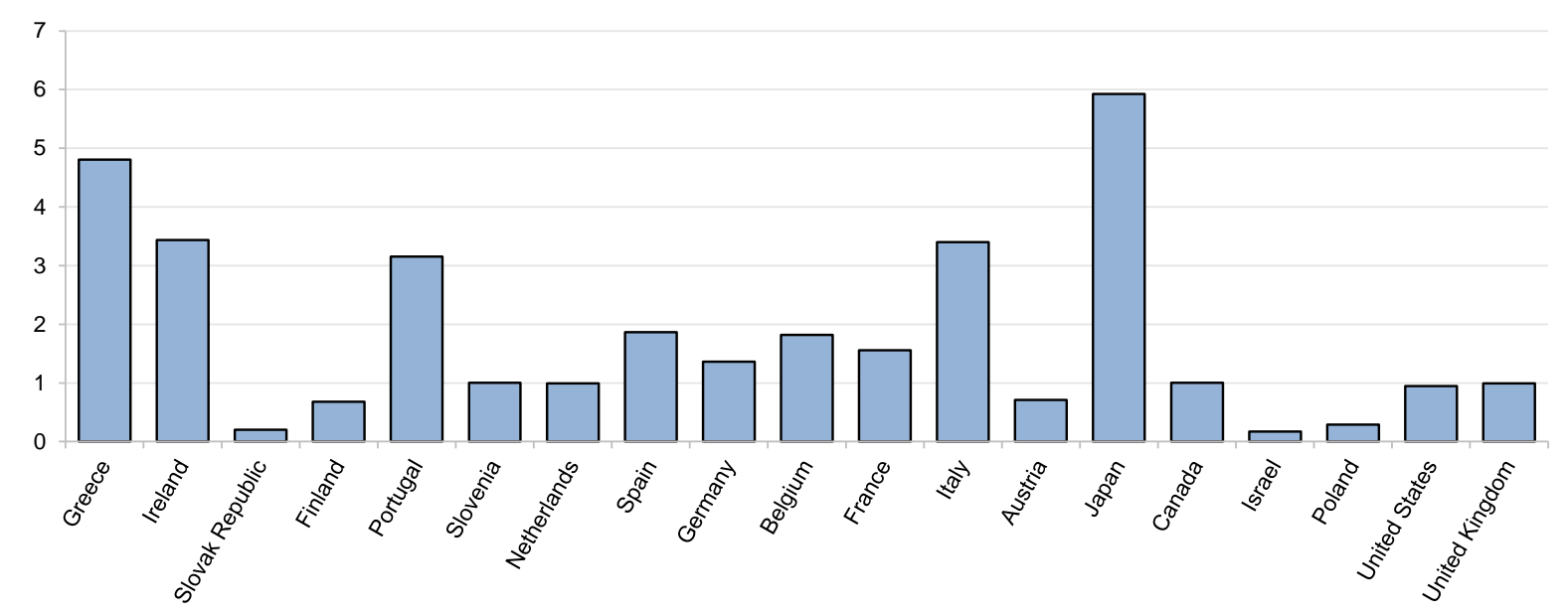

Note: The thick horizontal lines show the median debt level, boxes show the interquartile range, and extreme values are the $5^{\text {th }}$ and the $95^{\text {th }}$ percentiles. Only those countries that need to generate a primary surplus are shown.

Source: OECD calculations.

\section{Fiscal rules}

55. In this section, debt trajectories, associated fiscal balances and recession risks are investigated for various fiscal rules. This is a stylised exercise that illustrates the differences between different types of rules. For this purpose, the behaviour of the government is simplified and the room for discretion is only partially introduced in some rules. In practice, fiscal policy is more complex than these stylised rules and lets room for discretion.

56. A debt target to be reached in 2040 is set and simulations are run to investigate the role of fiscal rules on two outcomes: the debt trajectory and the risk of recession. The uncertainty surrounding the debt trajectory is assessed by the interquartile range of the debt level in 2040. The long-term recession risk is measured by the probability of GDP per capita growth to become negative. These outcomes are assessed 
assuming various fiscal behaviours of the government, so as to describe the role of fiscal rules in shaping debt trajectories and mitigating recession risks. In addition, the necessary primary balance required to reach a prudent level by 2040 is investigated for those countries that need to reach a prudent debt level.

57. In the baseline simulation, the annual budget plan is set so that the primary balance is equal to the target if the output gap is in line with expectations. During the year, the government lets the automatic stabilizers play around this plan (Equation 11). This primary balance target is set to zero for countries that do not need to generate a surplus to reach a prudent debt level by 2040 . For the other countries, the primary balance is adjusted so that the prudent debt level is reached in 2040. This baseline simulation lets the automatic stabilisers work during the year in the case of growth surprises.

$$
B_{t}=\text { balance target }+\alpha \cdot\left(g a p_{t}-E_{t-1}\left(g a p_{t}\right)\right)-r \cdot D_{t-1}
$$

where $B_{t}$ denotes the government balance, $\alpha$ is the elasticity of the primary balance to the output gap, gap $p_{t}$ denotes the output gap and $\mathrm{D}_{\mathrm{t}-1}$ denotes the debt ratio in the previous year.

\subsection{The trade-off between counter-cyclicality and debt uncertainty}

58. Two simulations are considered to investigate the counter-cyclical role of fiscal policy. In the first, the primary balance is kept constant (Equation 12). The difference between this simulation and the baseline can be regarded as capturing the effect of the automatic stabilisers. In a second one, the reaction of the structural balance to the output gap is assumed to be twice as large as the average one observed in the past (Equation 13). The difference between this simulation and the baseline illustrates the effect of adding discretionary policy changes on top of the automatic stabilisers.

$$
\begin{aligned}
& B_{t}=\text { balance target }-r \cdot D_{t-1} \\
& B_{t}=\text { balance target }+\alpha \cdot\left(g_{a p}-E_{t-1}\left(g_{a p}\right)\right)+\alpha \cdot g a p_{t}-r \cdot D_{t-1}
\end{aligned}
$$

59. The simulation illustrates the trade-off between counter-cyclicality and debt trajectory uncertainty (Figure 7): a counter-cyclical fiscal policy increases the uncertainty surrounding the debt level. The effectiveness of fiscal policy in damping short-term shocks can be assessed by the reduction of the recession risk when a government switches from a constant primary balance behaviour to a countercyclical behaviour. This effectiveness varies across countries. It is the lowest in Ireland, Luxembourg and Spain, while it is the highest in Australia, Belgium and Poland (Figure 7, Panel A). At the same time, it increases debt uncertainties the most in Finland, Poland and the United Kingdom, while it does not increase debt uncertainty in Luxembourg (Figure 7, Panel B). 
Figure 7. The trade-off between counter-cyclicality and hitting the debt target Panel A. Long-term recession risks

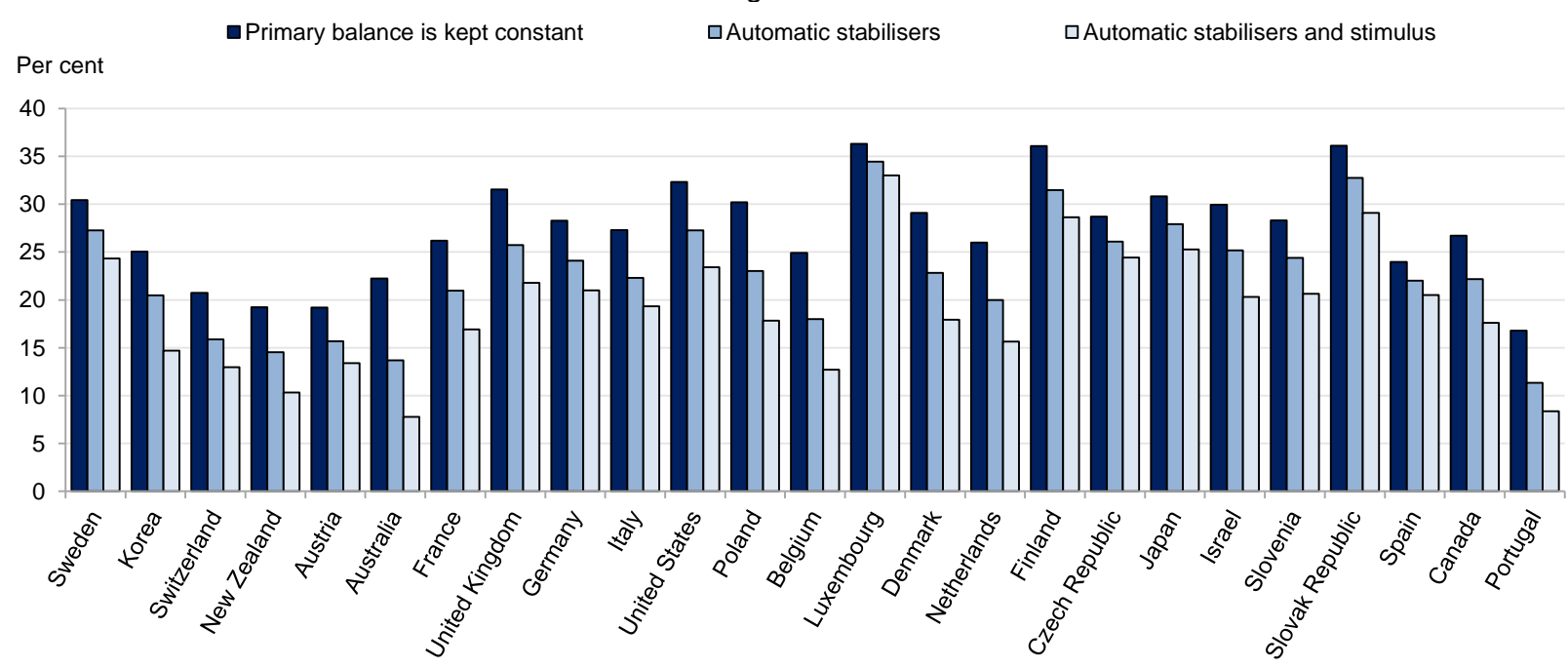

Panel B. Debt ratio uncertainties

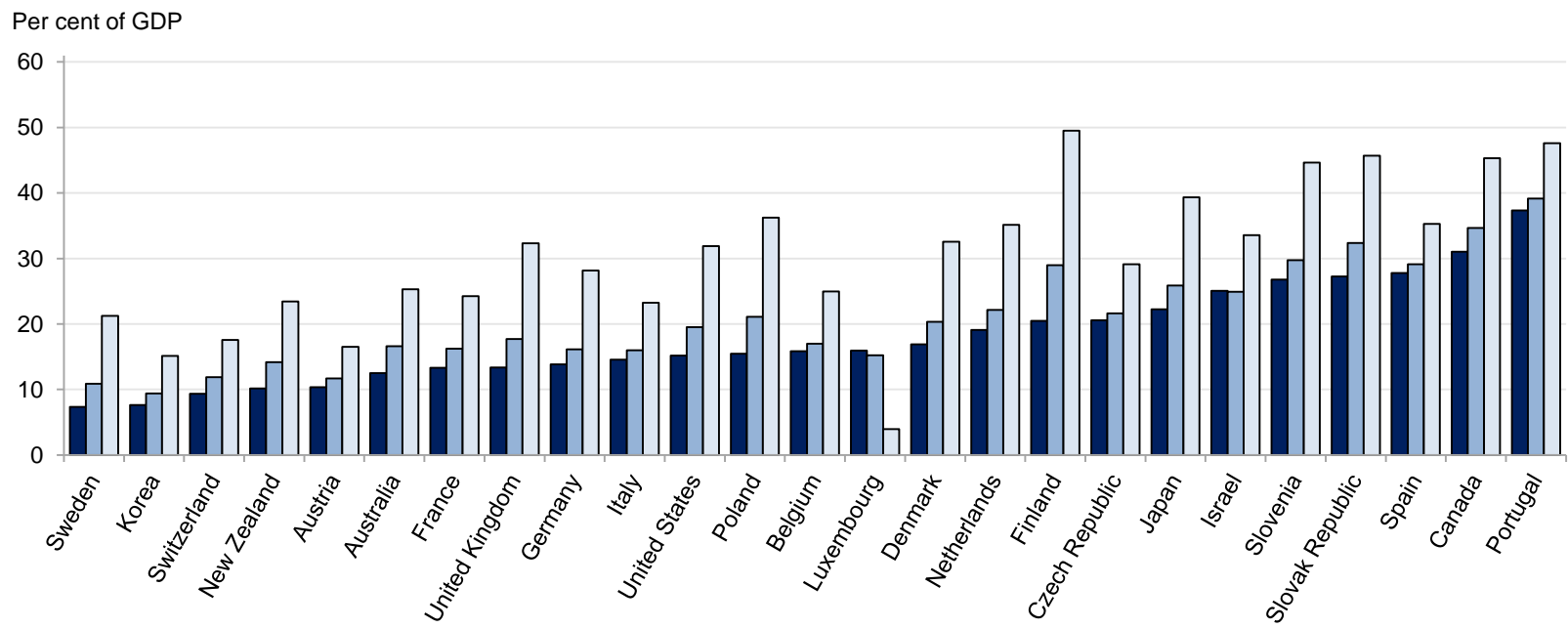

Note: The long-term recession risk is the probability of GDP per capita growth to become negative. The uncertainty surrounding the debt trajectory is assessed by the interquartile range of the debt level in 2040. The "Primary balance is kept constant" simulation is a stylised scenario in which the actual primary balance is kept constant such that the prudent debt target is reached, with no automatic stabilisers. In the scenario labelled "Automatic stabilisers", a 1 percentage point negative surprise in the output gap is associated with a stimulus of $0.4 \%$ of GDP. In the "Automatic stabilisers and stimulus" scenario, the government is taking discretionary measures on top of automatic stabilisers to react to changes in the output gap.

Source: OECD calculations.

60. A counter-cyclical fiscal policy can raise the average budget balance that is necessary to bring debt back to a prudent level by 2040. This is because the prudent debt level is lower, so as to keep the probability for debt to go above a given threshold unchanged. This is particularly an issue for those countries that need to consolidate most, such as Japan and some euro area countries (Figure 8). 
Figure 8. Counter-cyclical behaviour and primary balance needed to reach a prudent debt level

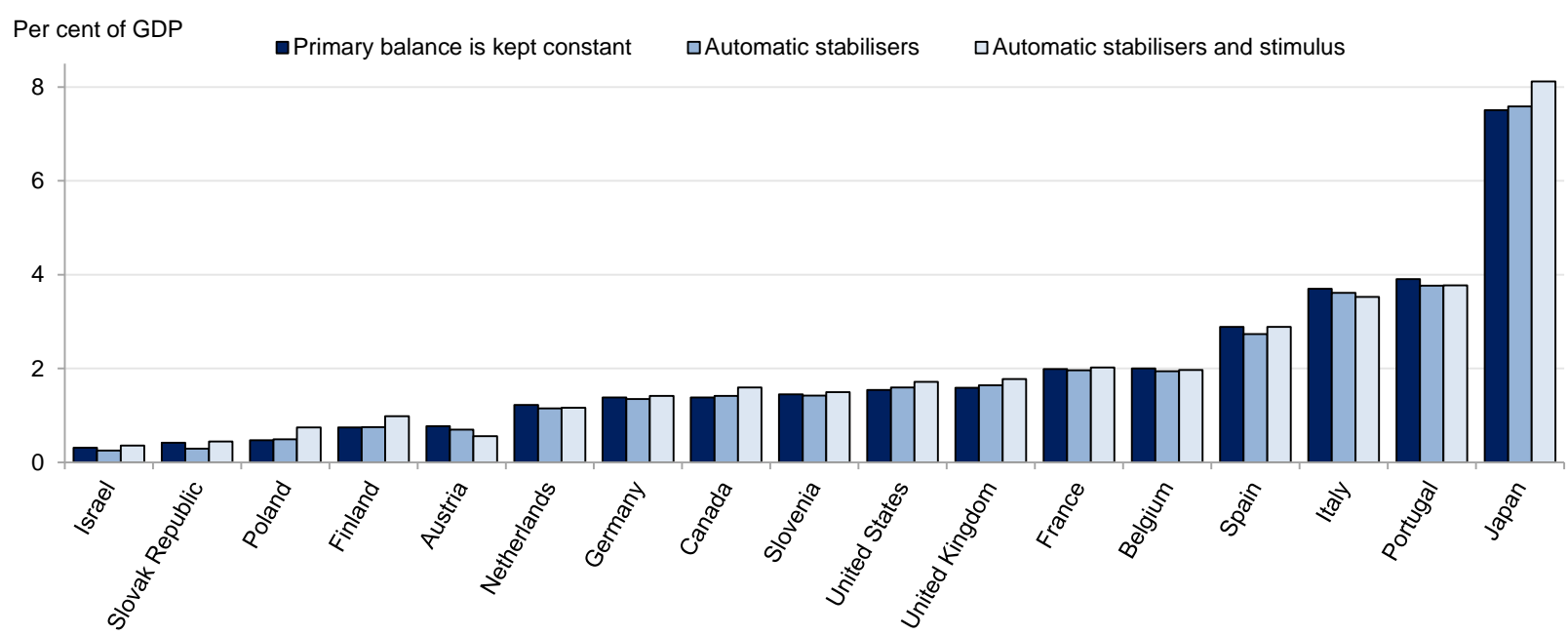

Note: The surplus reported here is the average primary balance between 2014 and 2040. The "Primary balance is kept constant" simulation is a stylised scenario in which the primary balance is kept constant such that the prudent debt target is reached, with no automatic stabilisers. In the scenario labelled "Automatic stabilisers", a 1 percentage point negative surprise in the output gap is associated with a stimulus of $0.4 \%$ of GDP. In the "Automatic stabilisers and stimulus" scenario, the government is taking discretionary measures on top of the automatic stabilisers to react to changes in the output gap.

Source: OECD calculations.

\subsection{A spending rule can boost long-term growth and hence reduce recession risks}

61. The effect of a spending rule is investigated in a simulation in which structural spending grows less fast than GDP so that the structural spending to GDP ratio decreases by 0.5 GDP point each year, for the countries with a structural spending level that is above the pre-crisis OECD average (37\% of GDP) (Equation 14). In this simulation, the primary balance follows the same path as in the baseline. As spending restraint increases potential growth, the whole distribution of possible growth outcomes is shifted up for those countries that have room to restrain spending, and hence the recession risk is reduced (Figure 9). At the same time, the uncertainty surrounding the debt path is not changed: this rule entails no particular trade-off. Countries that have the highest structural spending level, such as Denmark, Finland and France show the largest decline in recession risk.

$$
\left\{\begin{array}{c}
B_{t}=\text { balance target }+\alpha \cdot\left(g a p_{t}-E_{t-1}\left(g_{a p}\right)\right)-r \cdot D_{t-1} \\
S_{t}=\min \left(S_{t-1}-0.5, S^{T}\right) \text { if } S_{t-1}>S^{T}
\end{array}\right.
$$

where $S_{t}$ denotes the structural level of government spending in per cent of GDP and $S^{T}$ the targeted level of structural spending. 
Figure 9. A spending rule reduces the recession risk Probability that GDP per capita decreases

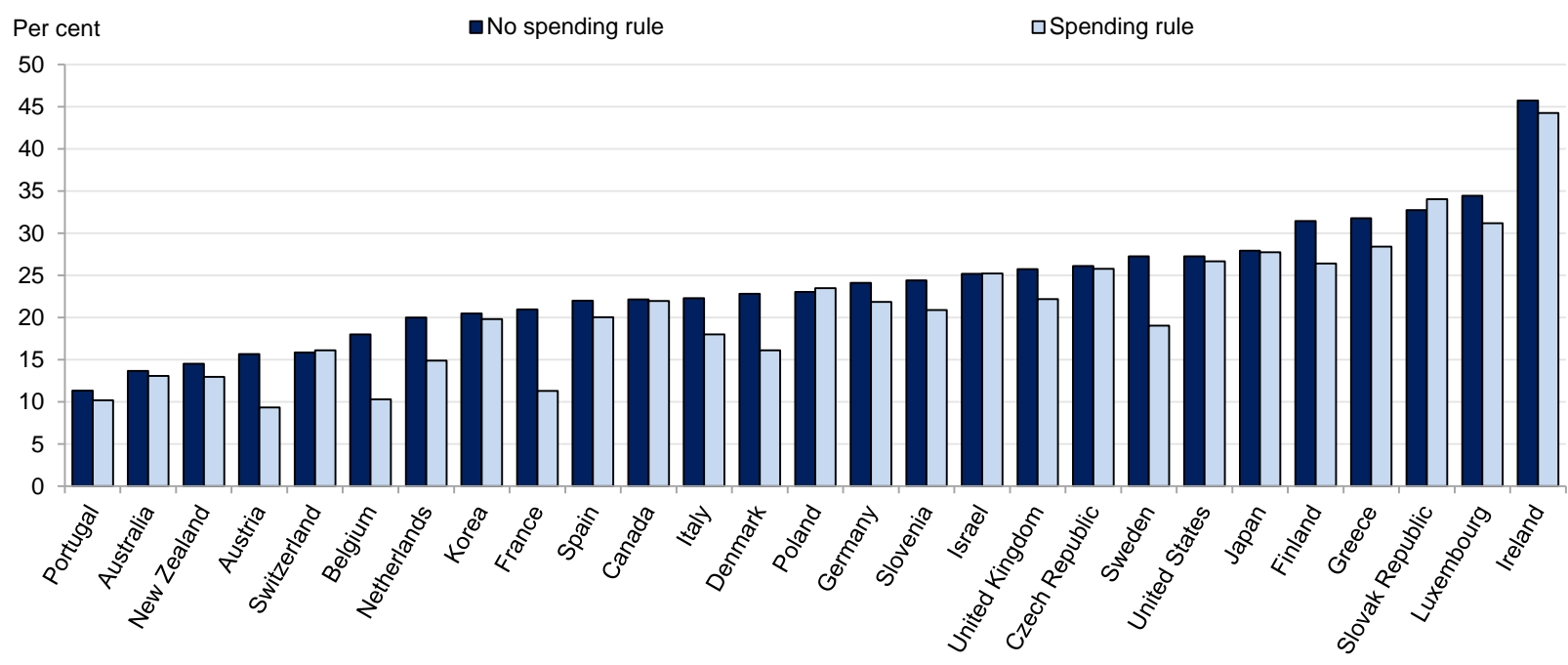

Note: The long-term recession risk is the probability of GDP per capita growth to become negative. In the scenario labelled "No spending rule", a 1 percentage point negative surprise in the output gap is associated with a stimulus of $0.4 \%$ of GDP. In the "Spending rule" scenario, on top of this rule, structural spending grows by 0.5 percentage points less than potential GDP, for countries for which the structural spending level is above the pre-crisis OECD average (37\%).

Source: OECD calculations.

\subsection{Restraining fiscal stimulus to the current year reduces debt uncertainty without adverse effects on recession risks}

62. An alternative simulation considers a government that keeps the structural balance constant, so that the automatic stabilisers play with no limit in time (Equation 15). By contrast, in the baseline simulation, if the output gap remains unchanged in the next year, the primary balance is brought back to its target. Letting automatic stabilisers play freely increases debt uncertainty (Figure 10). At the same time, recession risks are almost unchanged relative to the baseline scenario. This illustrates that fiscal stimulus that is restricted to temporary measures only is a good practice for virtually all countries. However, this conclusion holds under the assumption that changes of real growth due to fiscal policy have no effect on potential growth.

$$
B_{t}=\text { balance target }+\alpha \cdot g a p_{t}
$$


Figure 10. Temporary fiscal stabilisation reduces debt uncertainty Panel A. Long-term recession risks

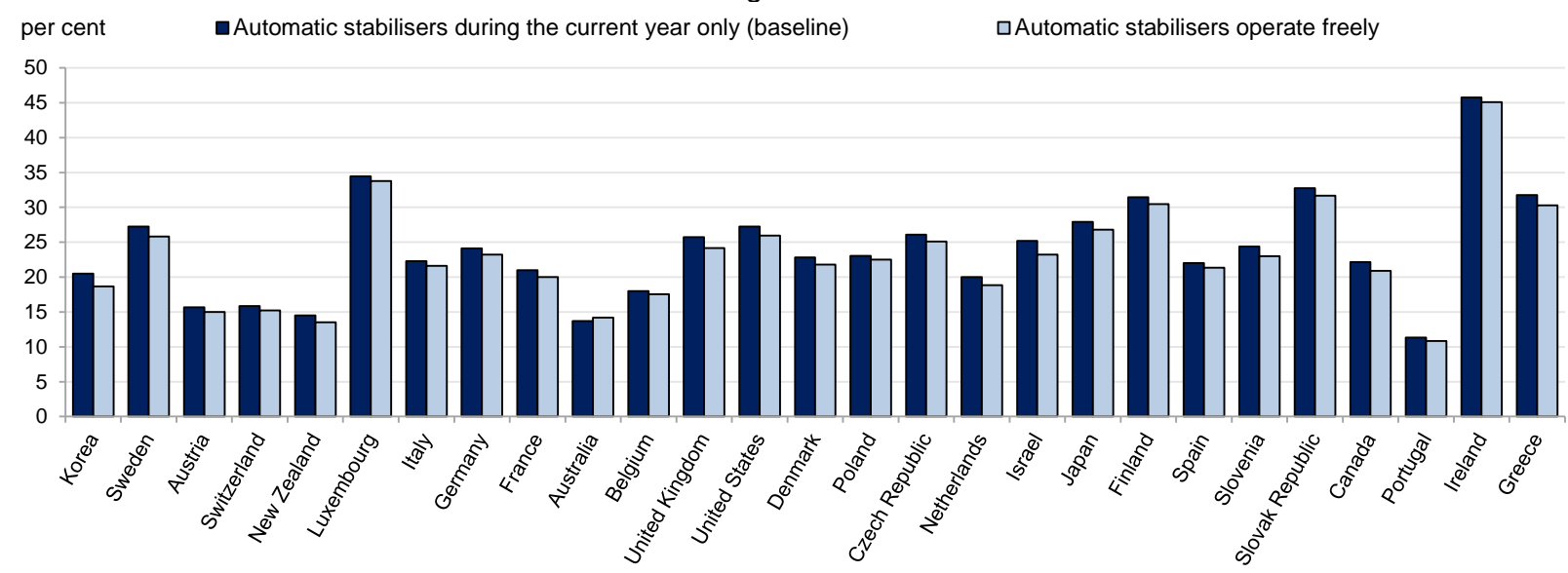

Panel B. Debt ratio uncertainties

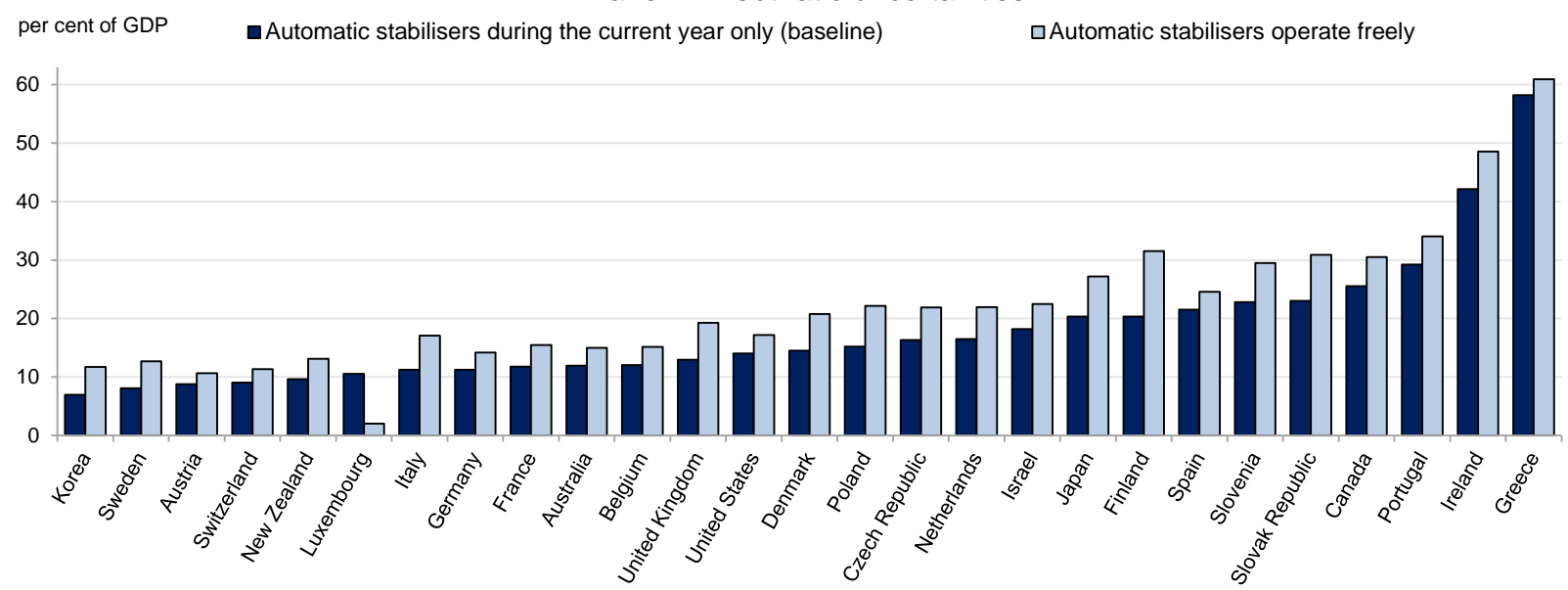

Note: The long-term recession risk is the probability of GDP per capita growth to become negative. The uncertainty surrounding the debt trajectory is assessed by the interquartile range of the debt level in 2040. In the baseline scenario, a 1 percentage point negative surprise in the output gap during the year is associated with a stimulus of $0.4 \%$ of GDP. In the "Automatic stabilisers operate freely" scenario, the structural balance is kept constant so that automatic stabilisers operate on a permanent basis.

Source: OECD calculations.

\subsection{Frontloading of consolidation can reduce debt trajectory uncertainties}

63. The role of frontloading is investigated with two simulations. In the first, if lagged debt is higher than the target, than the government generates an additional surplus equal to one $20^{\mathrm{th}}$ of the difference between lagged debt and this target (Figure 11 and Equation 16). This comes on top of a constant effort made otherwise, which is set with the aim to reach a prudent debt level by 2040. In the second simulation, the government's target is set in terms of the actual balance including interest payments, instead of the primary balance (Figure 12 and Equation 17). This forces the primary balance to be higher when a high debt level implies a high interest payment burden. Both alternatives reduce the uncertainty surrounding the debt level as a feedback force on the debt trajectory is created. However, both alternatives also provide little gain in terms of average surplus needed to reach the prudent debt target. They also have no visible impact on the recession risk in the long run, though these rules can have one in the short run.

$$
\begin{aligned}
& B_{t}=\text { balance target }+0.05 * \max \left(D_{t-1}-D^{T}, 0\right)+\alpha \cdot\left(g_{a p}-E_{t-1}\left(g a p_{t}\right)\right)-r \cdot D_{t-1} \\
& B_{t}=\text { balance target }+\alpha \cdot\left(g a p_{t}-E_{t-1}\left(g_{a p}\right)\right)
\end{aligned}
$$

where $\mathrm{D}^{\mathrm{T}}$ is the debt threshold. 
Figure 11. A debt feed-back rule reduces debt trajectory uncertainties

Panel A. Average recession risk over the consolidation period
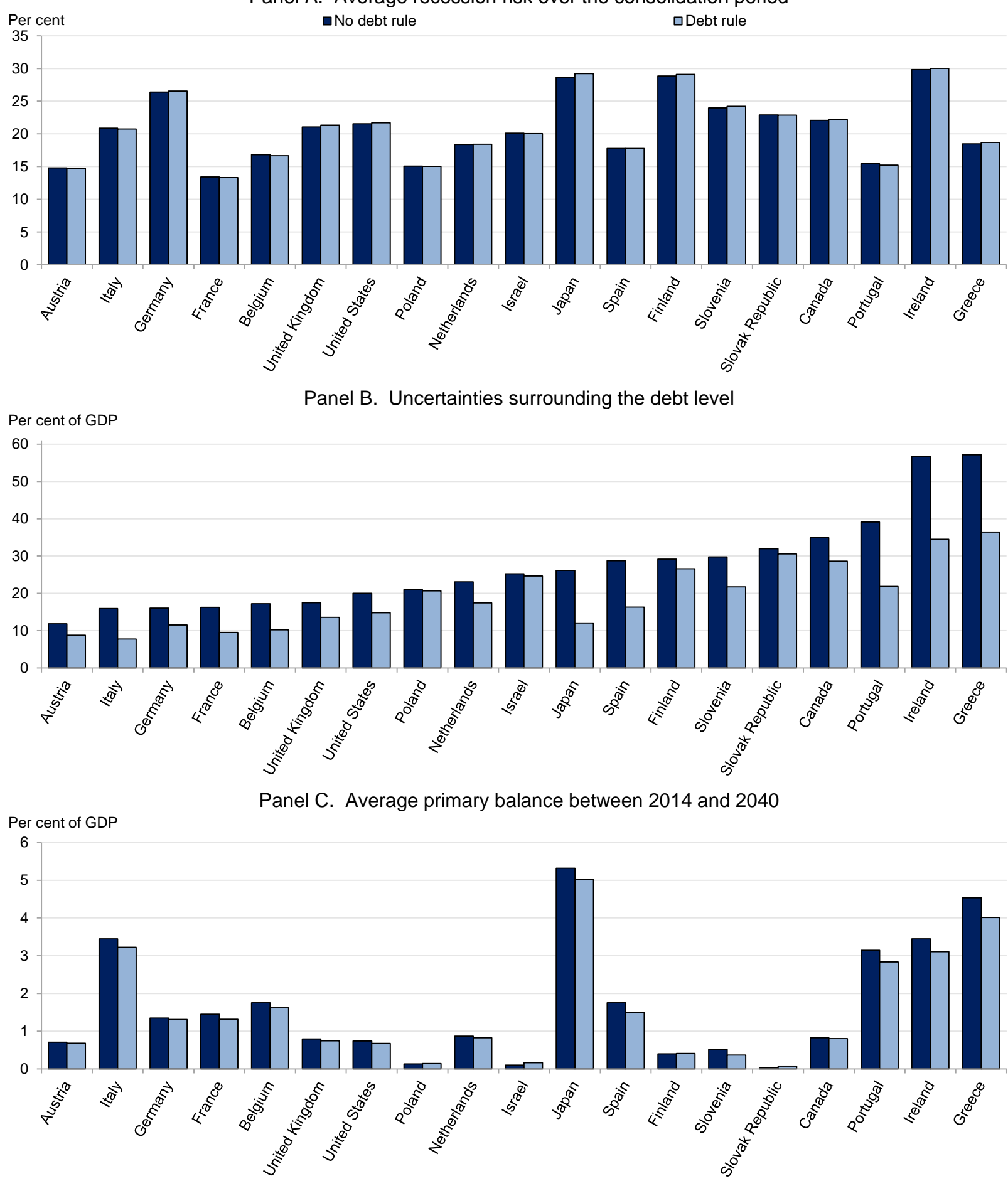

Note: The long-term recession risk is the probability of GDP per capita growth to become negative. The uncertainty surrounding the debt trajectory is assessed by the interquartile range of the debt level in 2040. The surplus reported here is the average primary balance between 2014 and 2040. In the baseline scenario, a 1 percentage point negative surprise in the output gap during the year is associated with a $0.4 \%$ of GDP stimulus. In the "Debt rule" or frontloading scenario, the primary balance is increased by one twentieth of the difference between the debt level and its ceiling when debt is above this ceiling. This comes on top of the effort made otherwise. This figure shows the countries that need to generate a primary surplus to reach a prudent debt level by 2040.

Source: OECD calculations. 
Figure 12. Including interest payments in the targeted balance reduces debt trajectory uncertainties

Panel A. Probability that GDP per capita decreases

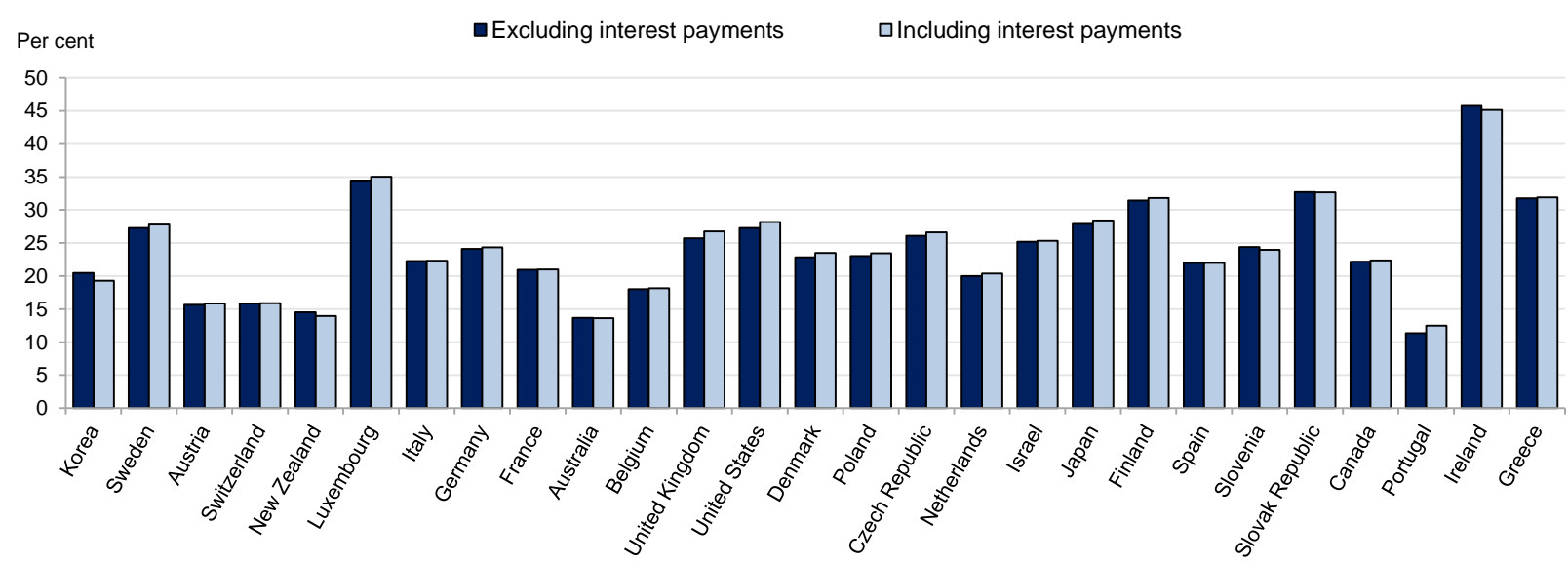

Panel B. Uncertainties surrounding the debt level

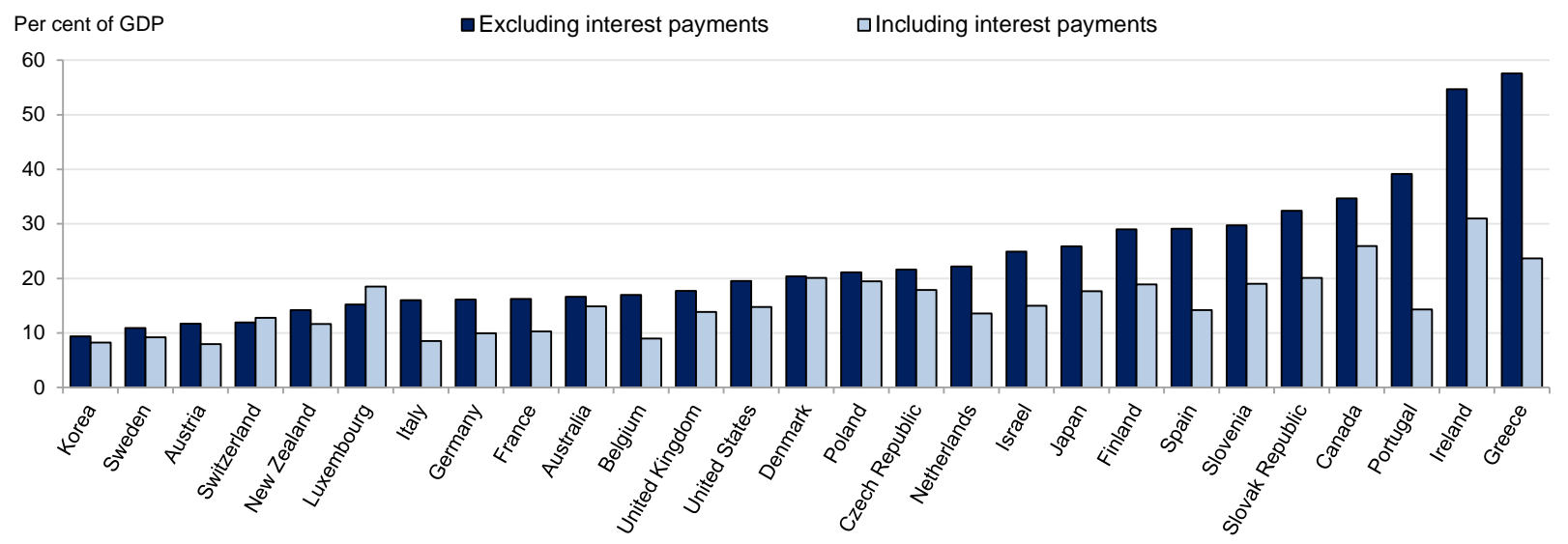

Note: The long-term recession risk is the probability of GDP per capita growth to become negative. The uncertainty surrounding the debt trajectory is assessed by the interquartile range of the debt level in 2040 . The surplus reported here is the average primary balance between 2014 and 2040. The "Excluding interest payment" scenario is the baseline scenario in which the primary balance is used as a target. The "Including interest payment" scenario is similar to the baseline scenario, except that the actual balance including interest payments is taken as a target.

Source: OECD calculations.

\subsection{Fiscal rules for country groups}

64. Countries are grouped into six groups depending on a combination of their characteristics and their responses to the different rules. Four criteria are used for the grouping of countries: the effectiveness of counter-cyclical fiscal policy, having room to restrain spending, belonging to the euro area ${ }^{7}$ and consolidation needs. In the first group are countries where fiscal policy has a strong counter-cyclical effect and where this strong effect does not have a large effect on the uncertainty surrounding the debt path. These countries are within the top 17 countries in terms of reduction of recession risk, so that the recession

7. Belonging to the euro area is a criterion, because of the absence of monetary policy at the country level. 
risk is reduced by more than $7 \%$ when comparing a policy of constant primary balance to a policy with automatic stabilisers and fiscal stimulus, and for which the uncertainty surrounding the debt-to-GDP ratio (measured in terms of interquartile range) is lower than 40 per cent of GDP (Figure 13). In the second group are countries with a low level of public spending and a moderate effectiveness of fiscal policy to damp short-term shocks. The third group includes countries that have room for spending restraint, but excluding those euro area countries that need to generate large primary surpluses. The fourth group includes the euro area countries that face a moderate need to consolidate and have room to restrain spending. The fifth group gathers euro area countries that need to raise the primary balance to $2 \%$ of GDP or even more to hit the prudent debt ratio in 2040. Last, Japan has such a high debt level that hitting a prudent debt target by 2040 would imply an unrealistically large fiscal tightening in the short run.

\section{Figure 13. Countries that can rely more on counter-cyclical fiscal policy}

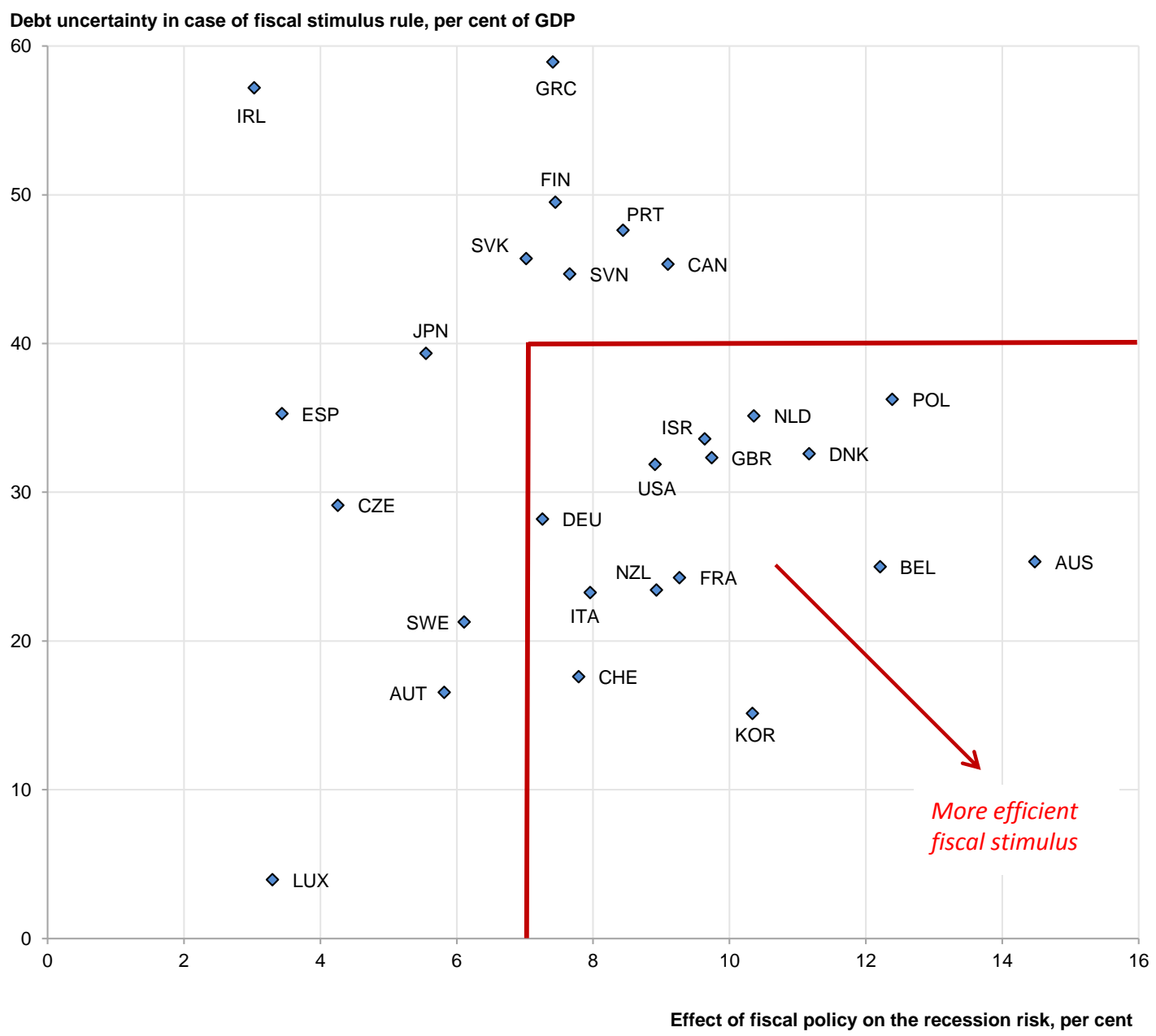


65. To sum up, countries can be gathered into six groups (Table 7 and Figure 14):

- Group 1 (Australia, Israel, Korea, New Zealand, Poland, Switzerland and the United States): Countries that can rely more on fiscal policy to mitigate short-term shocks. In these countries, a stronger reaction of fiscal policy to the cycle is efficient in reducing recession risks with a moderate cost in terms of debt uncertainty. Among these countries, the United States also needs to generate surpluses to bring debt back to a prudent level.

- Group 2 (Canada, Czech and Slovak Republic): Countries with a low level of public spending and a moderate effectiveness of fiscal policy to damp short-term shocks. The low level of public spending reveals there is little to gain from focusing on spending restraint, but a spending rule that makes sure this low level remains in the long run is appropriate. In these countries, countercyclical policy entails a considerable rise in debt uncertainty for a moderate reduction of recession risks.

- Group 3 (Denmark, Luxembourg, Sweden and the United Kingdom): These countries have room for spending restraint. These countries do not need to generate primary surpluses to target a prudent debt level by 2040, except the UK that needs to generate a moderate one. In Luxembourg and Sweden, a stronger reliance on fiscal policy to mitigate short-term shocks would increase debt uncertainty with moderate gains in terms of lowering recession risks.

- Group 4 (Austria, Belgium, Finland, France, Germany, the Netherlands and Slovenia): These euro area countries need to generate primary surpluses and Germany has to keep a primary surplus to bring debt back to a prudent level and they should restrain spending. These countries need both a spending and a debt rule to stick to the debt trajectory.

- Group 5 (Greece, Ireland, Italy, Portugal and Spain): These euro area countries need to generate large primary surpluses. These countries also face a large debt dynamics uncertainty. This uncertainty can be reduced with a debt rule, and by making sure that any widening of the primary balance triggered by a weaker economy is temporary. Because of the debt dynamics uncertainty, they have little room to mitigate recession risks with fiscal policy.

- Group 6 (Japan): The most indebted country is in a class of its own. Japan needs to reduce debt, but this process should be protracted as there is no strong adverse effect of the debt level on interest rates. Setting a prudent debt target by 2040 implies an unrealistic and unnecessarily large fiscal tightening in the short run. Counter-cyclical fiscal policy should not be used intensively as it leads to large debt trajectory uncertainty for quite a small reduction of recession risks. The low level of public spending suggests that most of the consolidation effort will have to come from the revenue side.

Table 7. Simulation results: Grouping of countries and fiscal rules

\begin{tabular}{|c|c|}
\hline Groups of countries & Rules \\
\hline $\begin{array}{l}\text { Group 1: Australia, Israel, Korea, New Zealand, Poland, } \\
\text { Switzerland and the United States }\end{array}$ & $\begin{array}{l}\text { Budget balance rule and considerable room for counter- } \\
\text { cyclical fiscal policy }\end{array}$ \\
\hline Group 2: Canada, Czech and Slovak Republic & Budget balance rule \\
\hline $\begin{array}{l}\text { Group 3: Denmark, Luxembourg, Sweden and the United } \\
\text { Kingdom } 1\end{array}$ & Budget balance rule and spending rule with some bite \\
\hline $\begin{array}{l}\text { Group 4: Austria, Belgium, Finland, France, Germany, the } \\
\text { Netherlands and Slovenia }\end{array}$ & Budget balance rule and spending rule with strong bite \\
\hline Group 5: Greece, Ireland, Italy, Portugal and Spain & $\begin{array}{l}\text { Budget balance rule that aims at a considerable primary } \\
\text { surplus with some frontloading }\end{array}$ \\
\hline Group 6: Japan & Considerable primary surplus with some frontloading \\
\hline
\end{tabular}

1. The United Kingdom has a spending-to-GDP ratio slightly above the OECD average, while the other countries in this group have high spending ratios.

Source: OECD calculations. 
Figure 14. Comparison of fiscal rules by country group

Panel A. Long-term recession risks

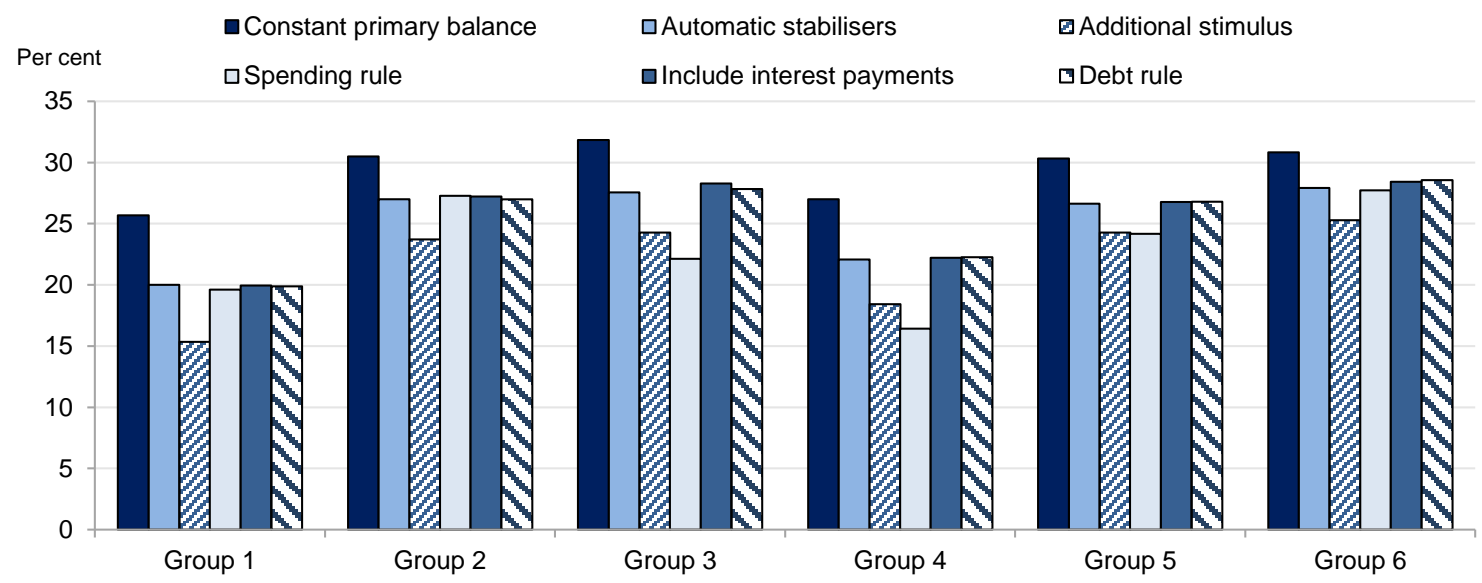

Panel B. Debt level uncertainties

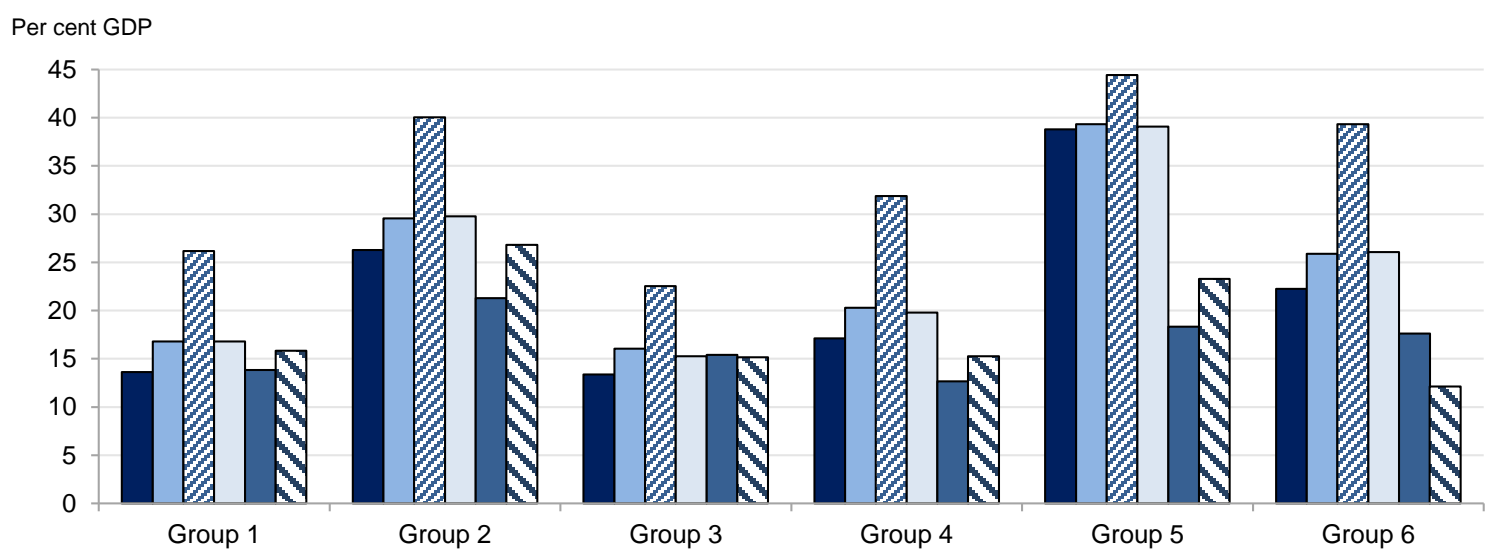

Note: The bars are averages for the countries in the group. The "Constant primary balance" simulation is a stylised scenario in which the actual primary balance is kept constant such that the prudent debt target is reached, with no automatic stabilisers. In the scenario labelled "Automatic stabilisers", a one percentage point negative surprise in the output gap is associated with a $0.4 \%$ of GDP temporary stimulus. In the "Additional stimulus" scenario, the government is taking discretionary measures on top of automatic stabilisers to react to the output gap. In the "Spending rule" scenario, the government lets the automatic stabilisers play during the current year only as in the baseline (rule 1); and structural spending grows by 0.5 percentage points less than potential GDP, for countries for which the structural spending level is above the pre-crisis OECD average (37\%) until it reaches this average. In the "Include interest payments" scenario, the government's target is set in terms of the actual balance including interest payments, instead of the primary balance. In the "Debt rule" or frontloading scenario, the primary balance is increased by one twentieth of the difference between the debt level and its ceiling when debt is above this ceiling. This comes on top of the effort made otherwise. The long-term recession risk is the probability that GDP per capita growth becomes negative. The uncertainty surrounding the debt trajectory is assessed by the interquartile range of the debt level in 2040.

Source: OECD calculations. 


\section{Robustness checks}

66. The comparison of the different types of rules is quite robust to changes in assumptions made for the simulations, albeit the macroeconomic dynamic depends on these assumptions. In this section, the sensitivity of the results to the following parameters is discussed:

- Growth rate and interest rates.

- $\quad$ Size of shocks.

- Use of gross or net debt.

- Time horizon of the consolidation.

- Tolerance level.

\subsection{Fiscal rules and the underlying macroeconomic scenario}

67. If potential growth were $1 \%$ higher than anticipated, while assuming at the same time that the interest rate follows the path in the baseline scenario, the recession risk, the consolidation need and the uncertainties surrounding the debt level would be lower (Figure 15). This effect crucially hinges on the assumption that the interest rate is unchanged. The relevant driving force is the difference between the interest rate and the growth rate (as discussed in Fournier and Fall, 2015) and if the interest rate were 1\% lower while the growth path is unchanged the effects would be similar. Country rankings remain broadly unchanged, and the comparison of rules would also present similar features as the mechanisms at work are unchanged. 
Figure 15. The effect of a higher potential growth rate

Panel A. Probability that GDP per capita decreases

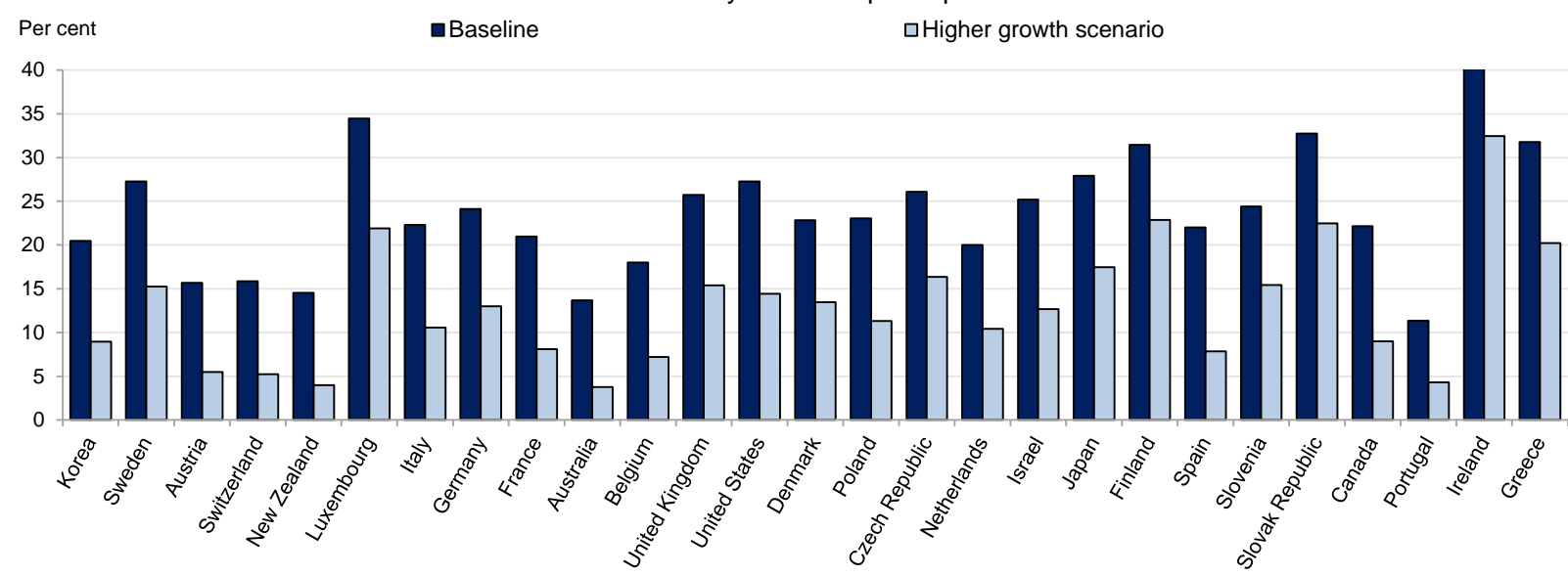

Panel B. Average primary balance between 2014 and 2040

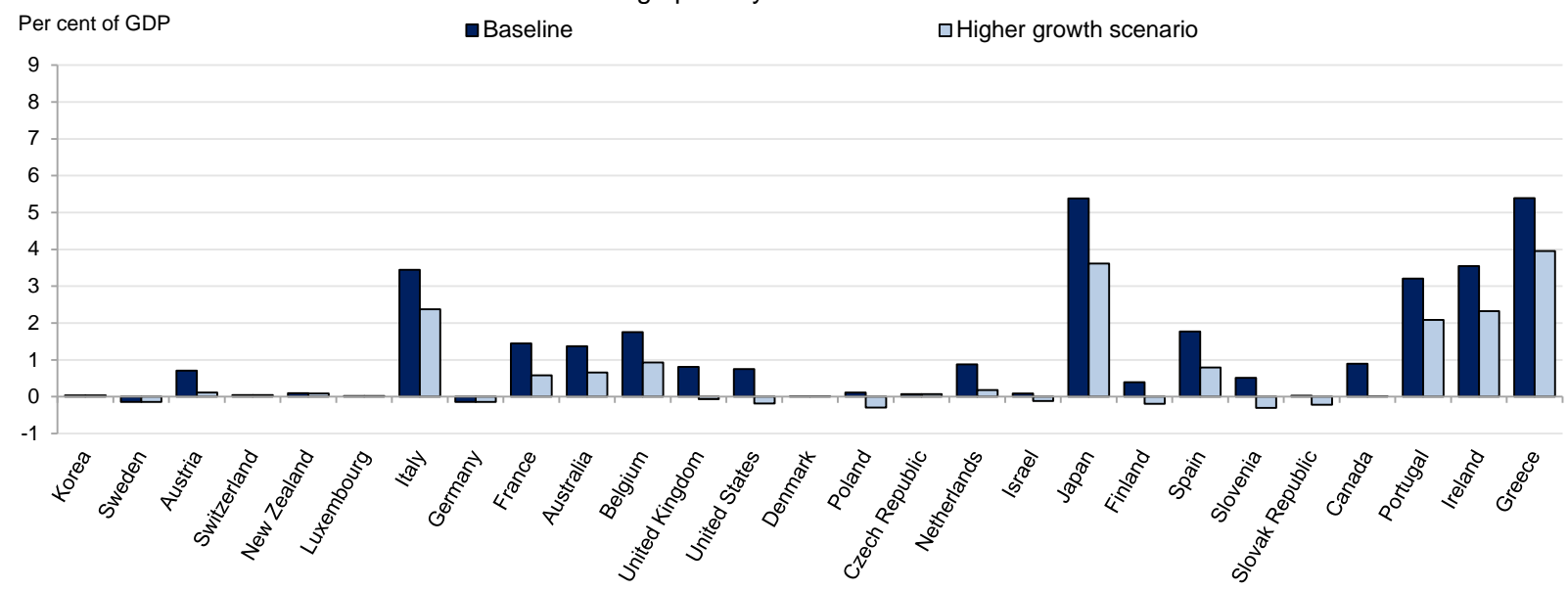

Panel C. Uncertainties surrounding the debt level

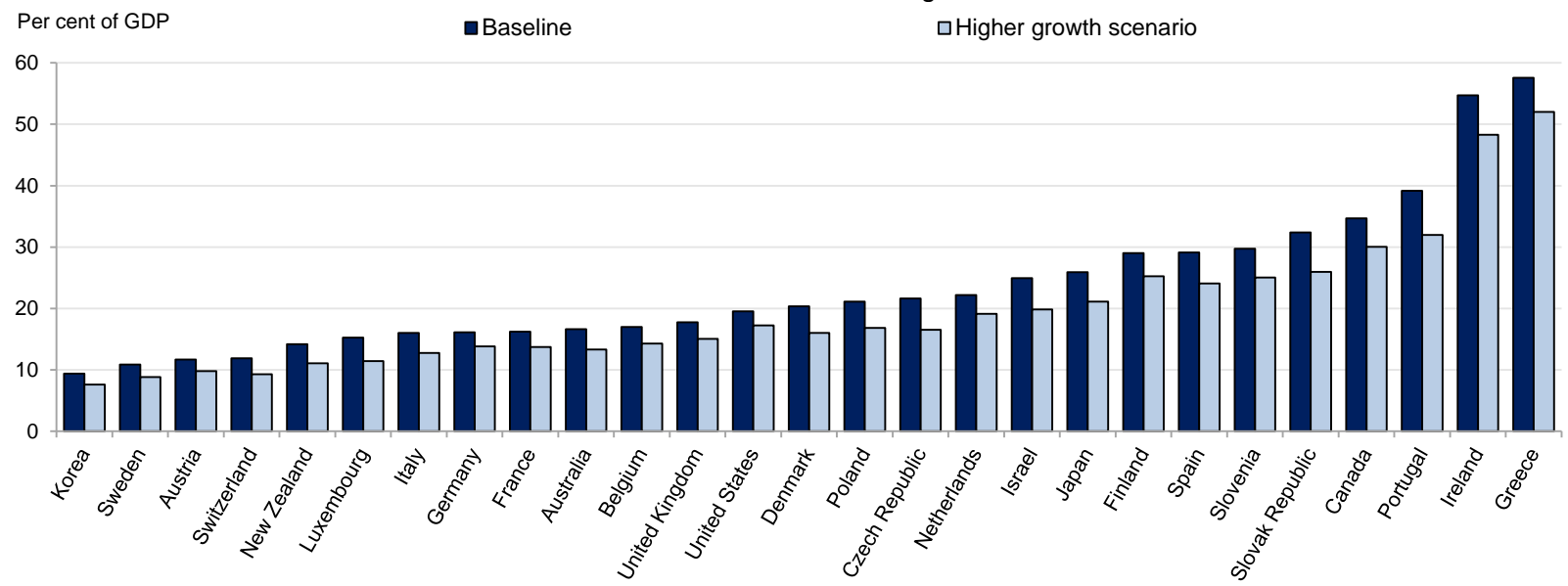

Note: The long-term recession risk is the probability of GDP per capita growth to become negative. The uncertainty surrounding the debt trajectory is assessed by the interquartile range of the debt level in 2040. In the baseline scenario, a one per cent negative surprise in the output gap is associated with a $0.4 \%$ of GDP temporary stimulus. In the scenario labelled "Higher growth", the potential growth rate is higher by 1 percentage point each year. Source: OECD calculations.

68. If the standard deviation of shocks were 50\% higher than those observed in the past, then the recession risk and the uncertainties surrounding the debt level would be higher and the consolidation need 
would remain broadly unchanged (Figure 16). The country ranking would remain broadly the same, and the comparison of rules would also present similar features.

Figure 16. The effect of larger shocks

Panel A. Probability that GDP per capita decreases
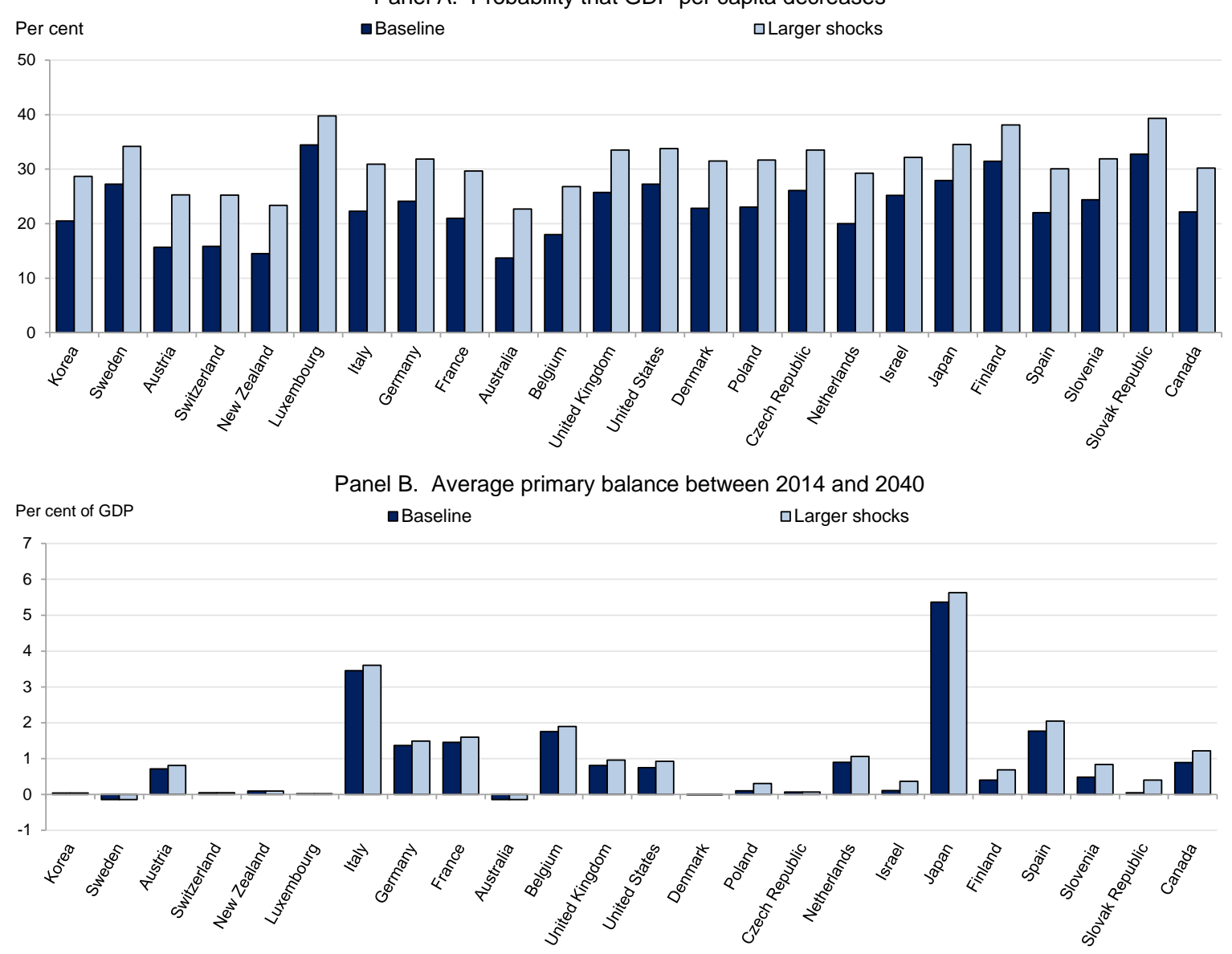

Panel C. Uncertainties surrounding the debt level

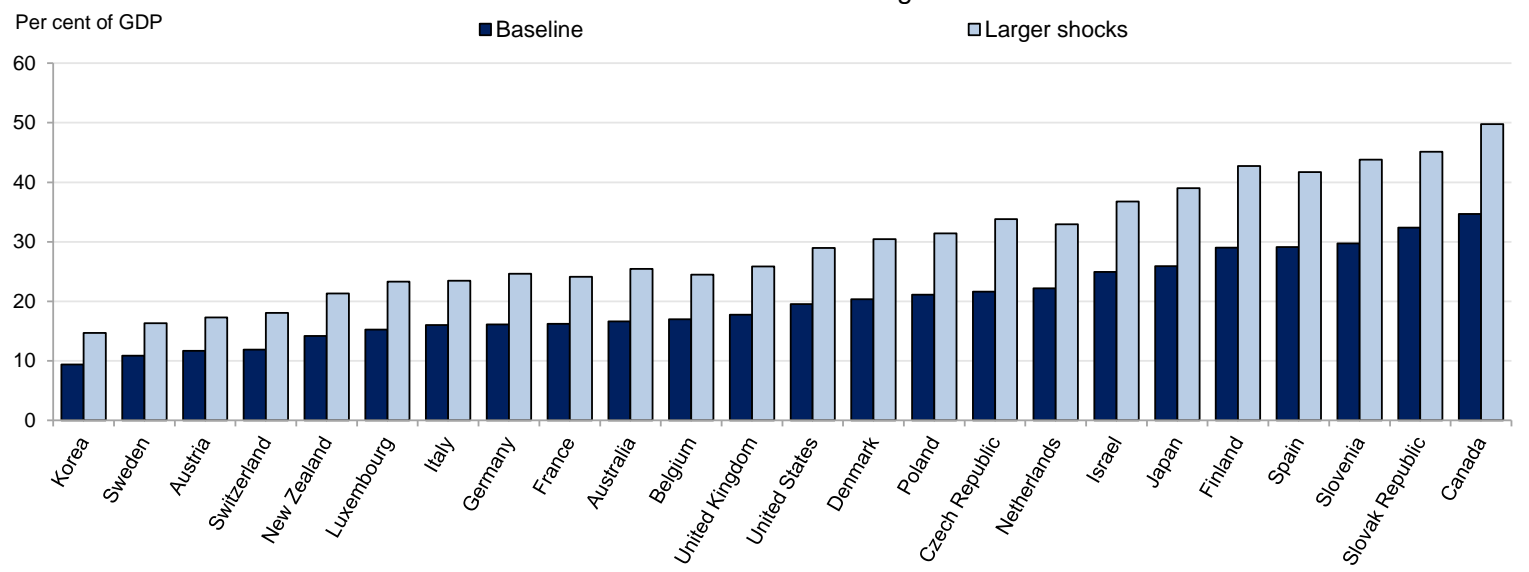

Note: The long-term recession risk is the probability of GDP per capita growth to become negative. The uncertainty surrounding the debt trajectory is assessed by the interquartile range of the debt level in 2040. In the baseline scenario, a one per cent negative surprise in the output gap is associated with a $0.4 \%$ of GDP temporary stimulus. In the scenario labelled larger shocks, the standard deviation of shocks is increased by $50 \%$. Results are not shown for Greece, Ireland and Portugal, for which observed shocks during the past are already much larger than for the OECD average.

Source: OECD calculations. 
69. The prudent debt levels shown here do not depend much on the choice of equations presented above. For instance, if one replaces the growth equation by the estimation in Column 2 of Table 1, the debt level trajectory under the no policy change scenario would be lower for most countries, as such a model would suggest a much more robust growth at the beginning of the simulation, and hence a more favourable output gap position. However, the size of uncertainties remains broadly unchanged, and hence the prudent debt target is little changed.

\subsection{Fiscal rules and assumptions made to reach prudent debt levels}

70. The same simulation can be run with net debt instead of gross debt (see the example of the Netherland in Figure 17). The mechanisms at work are the same if one replaces gross by net debt. The level of debt is modified substantially for those governments with large financial assets and hence the primary balance to keep debt at a prudent level is lower (Figure 17). However, the simulations with net debt do not take into account the uncertainties surrounding changes in financial asset valuation.

Figure 17. Net debt simulation: The example of the Netherlands

$\%$ of GDP
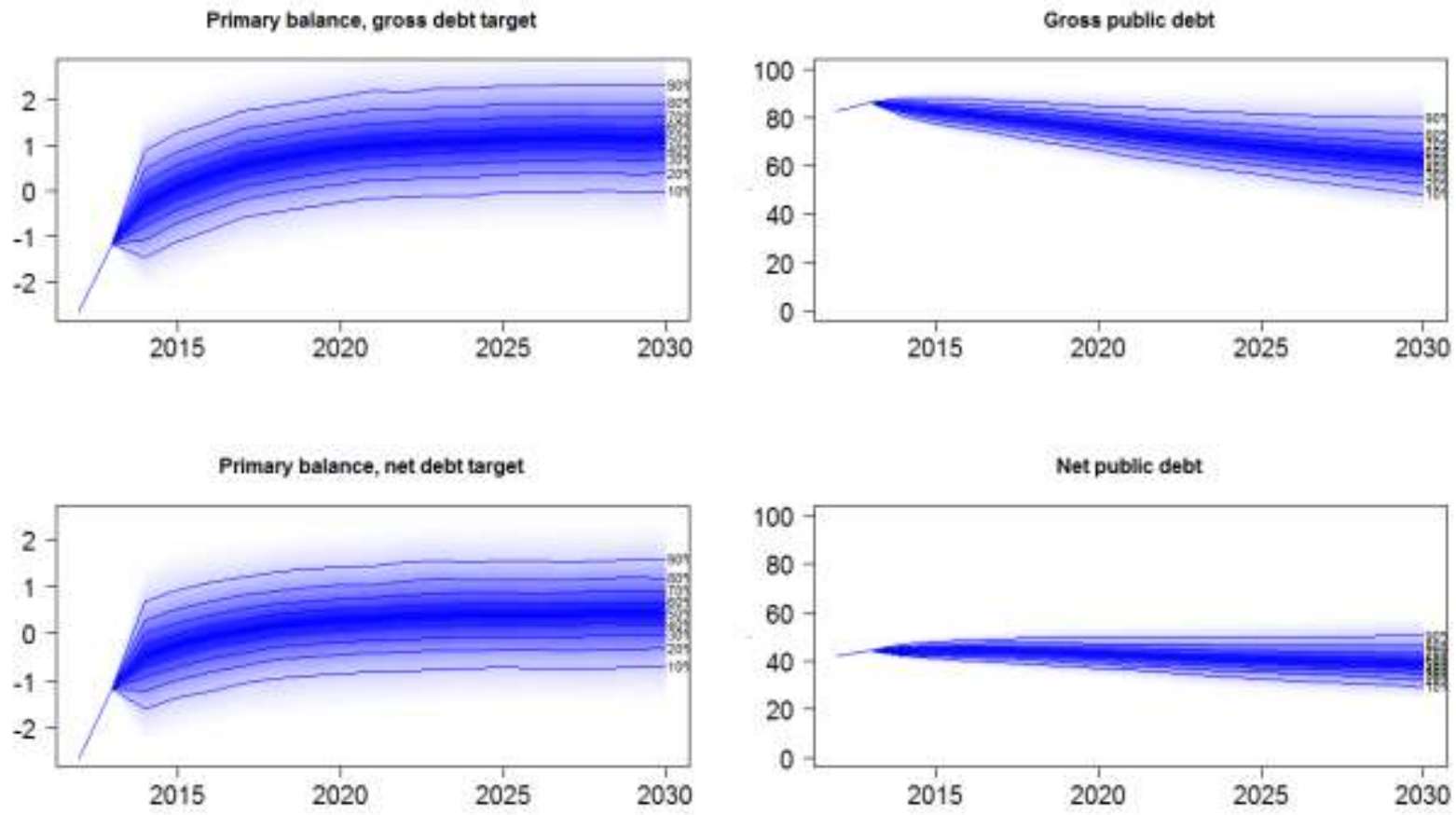

Source: OECD calculations.

71. Simulations run with a shorter horizon for consolidation, or with different debt thresholds, provide different debt trajectories, but the comparison of rules leads to similar conclusion. Shortening the duration of consolidation or lowering the debt threshold both mechanically imply more consolidation. At the same time, debt uncertainty ranges depend little on moderate variations of the debt thresholds: reducing the debt threshold by $10 \%$ of GDP is almost equivalent to reducing the debt target by $10 \%$ of GDP. 
72. Also the prudent debt targets increases with the tolerance (probability) level. A decrease of the tolerance probability (more stringency) from $25 \%$ to $10 \%$ decreases the prudent debt target for all countries (Figure 18, Panel A). The countries with the highest variance of shocks (Greece and Ireland) have the biggest decrease of their prudent debt target. Figure 18, Panel B illustrates the relationship between the tolerance level and the prudent debt target, taking the United States as example.

Figure 18. Sensitivity of prudent debt targets to the confidence level

Panel A. Prudent debt targets by country

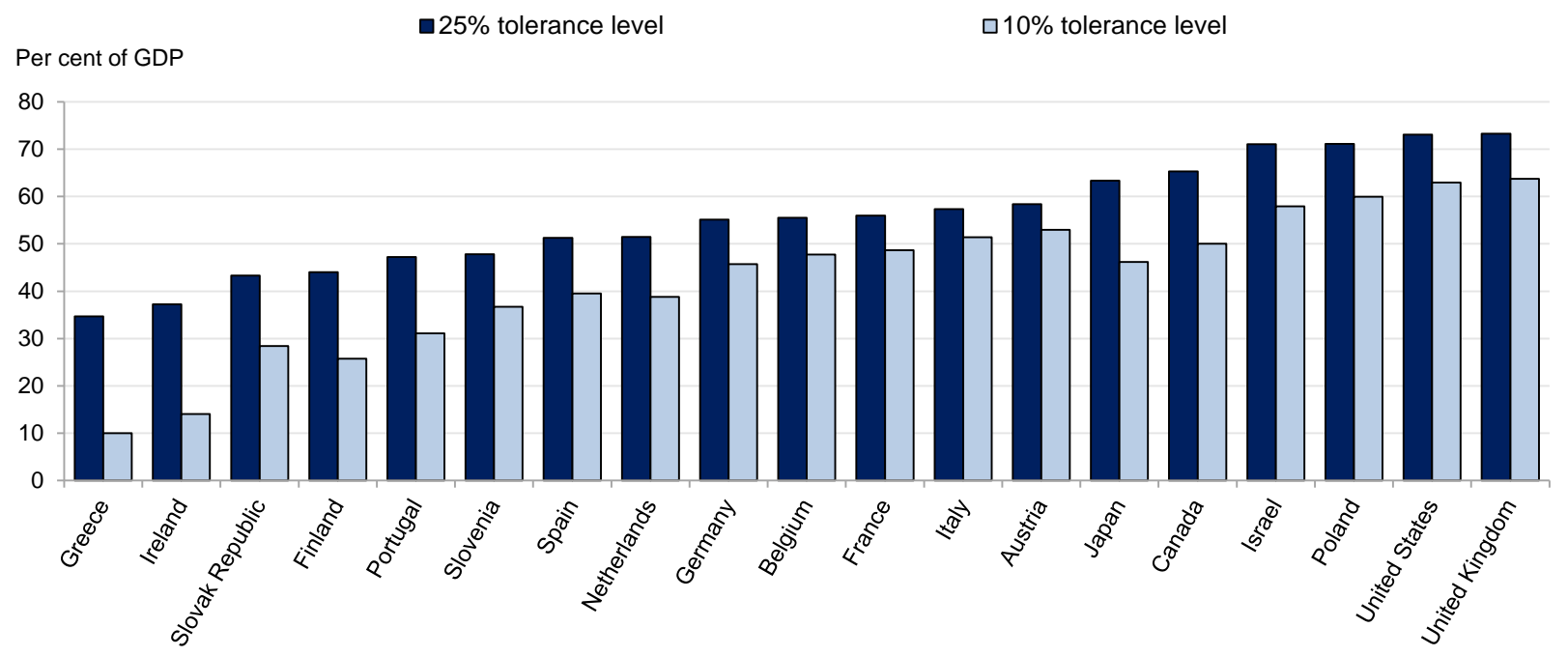

Panel B. Sensitivity to various tolerance levels (United States example)

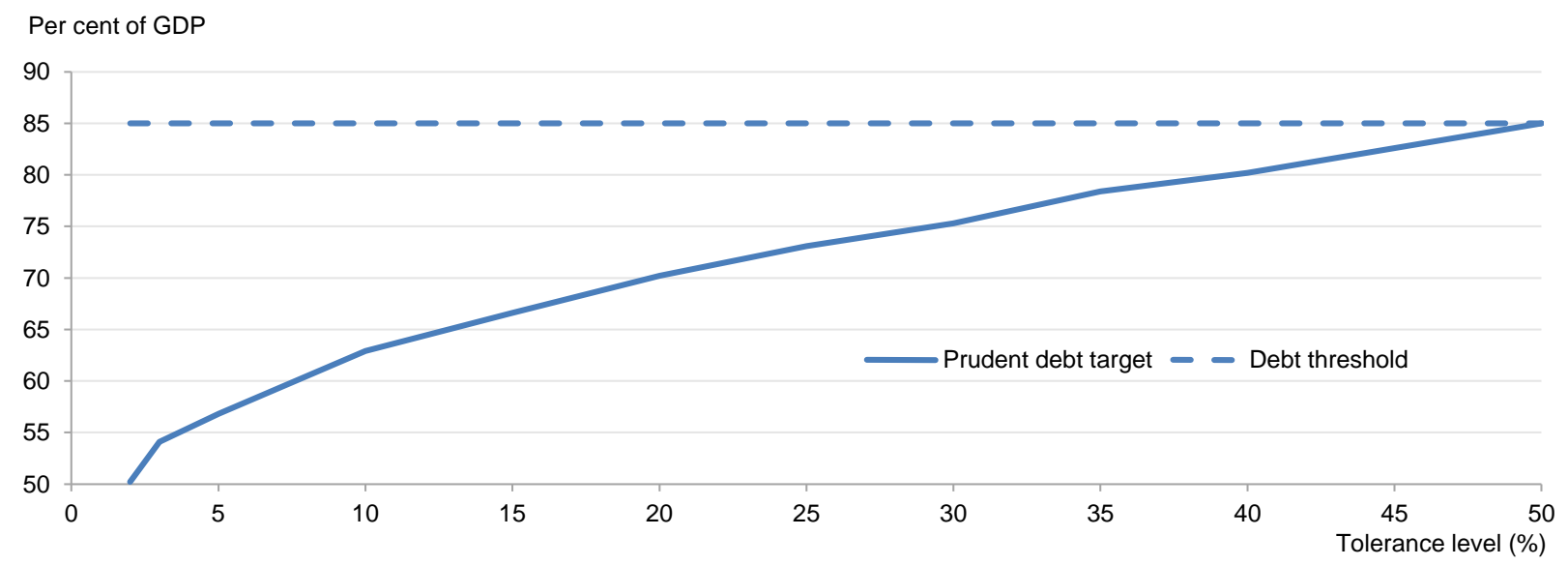

Note: This figure shows the sensitivity of the prudent debt level depicted in Figure 6 to a change of the tolerance level. Source: OECD calculations. 


\section{BIBLIOGRAPHY}

Afonso, A. and J. Alves ( 2014). "The Role of Government Debt in Economic Growth," Working Papers Department of Economics 2014/16, ISEG - School of Economics and Management, Department of Economics, University of Lisbon.

Aiyagari, R. S. and E. R. McGrattan (1998), “The Optimum Quantity of Debt”, Journal of Monetary Economics, Vol. 42, pp. 447-469.

Auerbach, A. and Y. Gorodnichenko (2012a), "Measuring the Output Responses to Fiscal Policy", American Economic Journal: Economic Policy, 4(2):1-27.

Auerbach, A. and Y. Gorodnichenko (2012b), "Fiscal Multipliers in Recession and Expansion", NBER Chapters, in Fiscal Policy after the Financial Crisis, pp. 63-98, National Bureau of Economic Research, Inc.

Auerbach, A. J. and L. J. Kotlikoff (1987), "Evaluating Fiscal Policy with a Dynamic Simulation Model”, American Economic Review, Vol. 77(2), pp. 49-55.

Barro, R. (1979), "On the Determination of Public Debt”, Journal of Political Economy, Vol. 87, pp. 940-971.

Barro, R.J. (1990), “Government Spending in a Simple Model of Endogenous Growth”, Journal of Political Economy, Vol. 98, No. 5, pp. 103-125.

Baum, A., Checherita - Westphal, C., and Rother, P. (2013), "Debt and Growth: New Evidence for the Euro Area", Journal of International Money and Finance, 32, 809 - 821.

Bergh, A. and M. Henrekson, (2011), "Government Size and Growth: A Survey and Interpretation of the Evidence”, Journal of Economic Surveys, Wiley Blackwell, Vol. 25(5), pp. 872-897.

Berti, K. (2013), "Stochastic Public Debt Projections Using the Historical Variance-Covariance Matrix Approach for EU Countries", Economic Papers, No. 480, European Commission.

Beynet, P. and E. Paviot (2012), “Assessing the Sensitivity of Hungarian Debt Sustainability to Macroeconomic Shocks under Two Fiscal Policy Reactions", OECD Economics Department Working Papers, No. 946, OECD Publishing, Paris.

Blanchard, O. J. and D., Leigh (2013), "Growth Forecast Errors and Fiscal Multipliers”, IMF Working Paper, 13/01.

Bloch, D. and F. Fall (2015), "Government Debt Indicators: Understanding the Data", OECD Economics Department Working Papers, No. 1228, OECD Publishing, Paris. 
Blöchliger, H. (2013), "Fiscal Consolidation across Government Levels - Part 1. How Much, What Policies?", OECD Economic Department Working Papers, No. 1070. OECD Publishing, Paris.

Bohn, H. (1998), "The Behavior of U.S. Public Debt and Deficits", The Quarterly Journal of Economics, Vol. 113(3), pp. 949-963.

Carlino G. and R. P. Inman (2013), "Local Deficits and Local Jobs: Can U.S. States Stabilize their own Economies?", NBER Working Paper, No. 18930.

Cecchetti, S., M. Mohanty and F. Zampolli ( 2011), "The Real Effects of Debt", BIS Working Papers, No. 352, Bank for International Settlements.

Checherita-Westphal, C., A. H. Hallett and P. Rother (2014), "Fiscal Sustainability Using Growthmaximizing Debt Targets", Applied Economics, Vol. 46(6), pp. 638-647.

Celasun, O., X. Debrun and J. D. Ostry (2007), "Primary Surplus Behavior and Risks to Fiscal Sustainability in Emerging Market Countries: A "Fan-ChartApproach", IMF Staff Papers, Vol. 53.

Chang, T. and G. Chiang (2009), "The Behavior of OECD Public Debt: A Panel Smooth Transition Regression Approach", The Empirical Economics Letters, Vol. 8(1).

Chudik, A., K. Mohaddes, H. Pesaran and M. Raissi (2013), "Debt, Inflation and Growth: Robust Estimation of Long-Run Effects in Dynamic Panel Data Models", Federal Reserve Bank of Dallas Globalization and Monetary Policy Institute Working Paper, No. 162.

Égert, B. (2013), “The 90\% Public Debt Threshold: The Rise and Fall of a Stylised Fact”, OECD Economics Department Working Papers, No. 1055, OECD Publishing, Paris.

Fall, F., D. Bloch, J-M. Fournier, and P. Hoeller (2015), "Prudent Debt Targets and Fiscal Frameworks", OECD Economic Policy Papers, No. 15, OECD Publishing, Paris.

Flodén, M. (2001), "The Effectiveness of Government Debt and Transfers as Insurance", Journal of Monetary Economics, Vol. 48(1), pp. 81-108.

Fournier, J-M. and F. Fall (2015), "Limits to Government Debt Sustainability”, OECD Economics Department Working Papers, No. 1229, OECD Publishing, Paris.

Galí, J., J. D. López-Salido, and J. Vallés (2007), "Understanding the Effects of Government Spending on Consumption", Journal of the European Economic Association, Vol. 5(1), pp. 227-70.

Garcia, M. and R. Rigobon (2004), "Risk Management Approach to Emerging Market's Sovereign Debt Sustainability with an Application to Brazilian Data", NBER Working Paper, No. 10336.

Gechert, S. and H. Will (2012), "Fiscal Multipliers: A Meta Regression Analysis", IMK Working Paper, 97-2012, IMK at the Hans Boeckler Foundation, Macroeconomic Policy Institute.

Ghosh, A. R., J. D. Ostry and M. S. Qureshi (2013), "Fiscal Space and Sovereign Risk Pricing in a Currency Union", Journal of International Money and Finance, Vol. 34, pp. 131-163.

di Giovanni, J. and E. Gardner (2008), "A Simple Stochastic Approach to Debt Sustainability Applied to Lebanon”, IMF Working Paper, No. 08/97. 
Girouard, N. and C. André (2005), "Measuring Cyclically-Adjusted Budget Balances for OECD Countries", OECD Economics Department Working Papers, No. 434, OECD Publishing, Paris.

De Grauwe, P. and Y. Ji (2012), "Self-Fulfilling Crises in the Eurozone: An Empirical Test", CEPS Papers, No. 7085, Centre for European Policy Studies.

Guillemette, Y. (2010), “A Simulation Model of Federal, Provincial and Territorial Government Accounts for the Analysis of Fiscal Consolidation Strategies in Canada", OECD Economics Department Working Papers, No. 818, OECD Publishing, Paris.

Guillemette, Y. and J. Strasky (2013), "Japan's Challenging Debt Dynamics”, OECD Economics Department Working Papers, No. 1085, OECD Publishing, Paris.

Haugh, D., P. Ollivaud and D. Turner (2009), "What Drives Sovereign Risk Premiums? An Analysis of Recent Evidence from the Euro Area", OECD Economics Department Working Papers, No. 718, OECD Publishing, Paris.

Heathcote, J. (2005), "Fiscal Policy with Heterogeneous Agents and Incomplete Markets", Review of Economic Studies, Vol. 72(1), pp. 161-188.

Hepp, R. and J. von Hagen (2009), "Fiscal Federalism in Germany: Stabilization and Redistribution Before and After the Unification”, CEPR Discussion Paper, No. 7246.

Herndon, T., M. Ash and R. Pollin (2013), "Does High Public Debt Consistently Stifle Economic Growth? A Critique of Reinhart and Rogoff," Working Papers wp322, Political Economy Research Institute, University of Massachusetts at Amherst.

Kneller, R., M.F. Bleaney and N. Gemmell (1999), "Fiscal Policy and Growth: Evidence from OECD Countries", Journal of Public Economics, 74, pp. 171-190.

Kumar, M. S. and J. Woo (2010), "Public Debt and Growth", IMF Working Paper, No. 10/174, International Monetary Fund.

Lucas, R. Jr. and N. L. Stokey (1983), "Optimal Fiscal and Monetary Policy in an Economy without Capital”, Journal of Monetary Economics, Vol. 12(1), pp. 55-93.

Martin, F. M. (2009), “A Positive Theory of Government Debt”, Review of Economic Dynamics, Vol. 12, pp. 608-631.

McGrattan, E. R. (1994), “The Macroeconomic Effects of Distortionary Taxation”, Journal of Monetary Economics, Vol. 33(3), pp. 573-601.

Mitchell, W. and W. Mosler (2002), "Public Debt Management and Australia's Macroeconomic Priorities", Centre of Full Employment and Equity Working Paper, No. 02-13, November 2002.

Nickel, C. and A. Tudyka (2014), "Fiscal Stimulus in Times of High Debt: Reconsidering Multipliers and Twin Deficits", Journal of Money, Credit and Banking, Vol. 46, Issue 7, pp. 1313-1344.

Orr, A., M. Edey and M. Kennedy (1995), "The Determinants of Real Long-Term Interest Rates: 17 Country Pooled-Time-Series Evidence", OECD Economics Department Working Papers, No. 155, OECD Publishing, Paris. 


\section{ECO/WKP(2015)48}

Panizza, U. and A. F. Presbitero (2014), "Public Debt and Economic Growth: Is there a Causal Link?", Journal of Macroeconomics, Vol. 41, pp. 21-41.

Ramey, V. (2011), “Can Government Purchases Stimulate the Economy?”, Journal of Economic Literature, Vol. 49(3), pp. 673-685.

Reinhart, C.M. and K.S. Rogoff (2010), "Growth in a Time of Debt", American Economic Review, Vol. 100, No. 2, pp. 573-78.

Roehn, O. (2010), "New Evidence on the Private Saving Offset and Ricardian Equivalence", OECD Economics Department Working Papers, No. 762, OECD Publishing. Paris.

Rothenberg, T. J. and J. H. Stock (1997), "Inference in a Nearly Integrated Autoregressive Model with Non-normal Innovations", Journal of Econometrics, Vol. 80, Issue 2, pp. 269-286.

Smets, F. and R. Wouters (2007), "Shocks and Frictions in US Business Cycles: A Bayesian DSGE Approach", American Economic Review, Vol. 97(3), pp. 586-606.

Sorbe, S. (2012), "Portugal - Assessing the Risks Around the Speed of Fiscal Consolidation in an Uncertain Environment", OECD Economics Department Working Papers, No. 984, OECD Publishing.

Strasky, J. (2015), "Public Capital Stock and the Debt-to-GDP Ratios in 22 OECD Countries", OECD Economic Department, mimeo, forthcoming.

Taylor, J. (1993), "Discretion versus Policy Rules in Practice", Carnegie-Rochester Conference Series on Public Policy, Vol. 39, December 1993, Pages 195-214.

Turner, D. and F. Spinelli (2013), "The Effect of Government Debt, External Debt and their Interaction on OECD Interest Rates", OECD Economics Department Working Papers, No. 1103, OECD Publishing, Paris.

Vogel, E. (2014), "Optimal Level of Government Debt: Matching Wealth Inequality and the Fiscal Sector", European Central Bank Working Papers Series, No. 1665. 